
\title{
Besearch S Surare \\ Optical, Thermal and Radiation Shielding Properties of B2O3 - NaF - PbO - BaO - La2O3 Glasses
}

\section{Kh.S.Shaaban ( $\nabla$ khamies1078@yahoo.com )}

Al Azhar university https://orcid.org/0000-0002-5969-3089

\section{Research Article}

Keywords: glasses, DTA, UV-VIS, Phy-X / PSD, FNRCS

Posted Date: February 19th, 2021

DOl: https://doi.org/10.21203/rs.3.rs-217044/v1

License: (a) (i) This work is licensed under a Creative Commons Attribution 4.0 International License.

Read Full License

Version of Record: A version of this preprint was published at Journal of Materials Science: Materials in Electronics on April 17th, 2021. See the published version at https://doi.org/10.1007/s10854-021-058858. 


\section{Optical, thermal and radiation shielding properties of $\mathrm{B}_{2} \mathrm{O}_{3}-\mathrm{NaF}-\mathrm{PbO}-\mathrm{BaO}-\mathrm{La}_{2} \mathrm{O}_{3}$ glasses}

Kh. S. Shaaban ${ }^{1}$,

${ }^{1}$ Chemistry Department, Faculty of Science, Al-Azhar University, P.O. 71452, Assiut, Egypt.

\section{Abstract}

The techniques of melt-quenching were used to generate $53 \mathrm{~B}_{2} \mathrm{O}_{3}-2 \mathrm{NaF}-27 \mathrm{PbO}-$ $(20-x) \mathrm{BaO}-x \mathrm{La}_{2} \mathrm{O}_{3}(0 \leq x \geq 15)$ glass system. XRD patterns have established the amorphous character of glass samples. There is clear evidence of the role of $\mathrm{La}_{2} \mathrm{O}_{3}$ modifier in the glass network. The thermal characteristics were identified to increase with an increase in $\mathrm{La}_{2} \mathrm{O}_{3}$ content. Increasing $\mathrm{La}_{2} \mathrm{O}_{3}$ increases the linear and non-linear optical bandgap energy and the Urbach energy. By adding $\mathrm{La}_{2} \mathrm{O}_{3}$ to the glass samples, the refractive index, molar polarizability, polarizability, and optical basicity are increased. Theoretically, the bulk modulus and the glass transition temperature increase because of the increase in bond strength. The number of bonds per unit increased with the increase in $\mathrm{La}_{2} \mathrm{O}_{3}$ content because of the modifier character of $\mathrm{La}_{2} \mathrm{O}_{3}$ in the glass samples. Multiple optical parameters $\left(\square^{\infty}\right),\left(\square_{0}\right)$, $\chi^{(1)},\left(\chi^{(3)}\right)$ and $\left(n_{2}\right)$ as a function of linear and non-linear $E_{\text {opt }}$ were obtained. The extent of shielding in this article was examined with the increment in $\mathrm{La}_{2} \mathrm{O}_{3}$ at the expense of $\mathrm{BaO}$. The results correspond with similar studies conducted previously.

Keywords: glasses, DTA, UV-VIS, Phy-X / PSD, FNRCS.

\section{Corresponding Author: khamies1078@yahoo.com}




\section{1-Introduction}

We have been aware of halide glasses such as $\mathrm{NaF}$ for just a long time [1]. These glasses are fundamentally hygroscopic and have low transition temperature glass values, thereby decreasing their potential application. To increase hygroscope resistance, these glasses were doped with transition metal ions (TMi) and rare earth ions (REi) [2-3]. Halides such as $\mathrm{NaF}, \mathrm{LiF}$, are incorporated into the glass matrix to develop mobile ion species, $\mathrm{Li}^{+}, \mathrm{Na}^{+}$, etc. Due to its unique characteristics, glasses combining halide ions have been studied [1-7]. The modified fluoroborate glasses manufactured by the substitution of certain oxygen ions with fluoride ions have shown interesting and motivating characteristics [8-11].

Due to the importance of glass materials containing multiple transition metal ions (TMi) and rare earth ions (REi) for multiple applications, these glasses have been intersected over the past few years. In specific, the glass based on $\mathrm{B}_{2} \mathrm{O}_{3}$ has become common among a wide variety of glass systems, keeping in mind its glass status, transparency, and multiple physical and chemical properties. Due to the ability of the B to transform its coordination number between 3 and 4 with oxygen supplying with the modification of metal cations, these glasses are considered important [12-22].

$53 \mathrm{~B}_{2} \mathrm{O}_{3}-2 \mathrm{NaF}-27 \mathrm{PbO}-(20-x) \mathrm{BaO}-x \mathrm{La}_{2} \mathrm{O}_{3}(0 \leq x \geq 15)$, glasses as well gain significant interest, and $\mathrm{La}_{2} \mathrm{O}_{3}$ to investigate their optical properties. These glasses are of financial advantage to semiconductor applications because of their properties: a greater refractive index, good unique physical and chemical characteristics. The creativity of this research paper is reflected in the optical and radiation shielding characteristics of $\mathrm{B}_{2} \mathrm{O}_{3}-\mathrm{NaF}-$ $\mathrm{PbO}-\mathrm{BaO}-\mathrm{La}_{2} \mathrm{O}_{3}$ glass samples. Results from thermal, optical, and radiation are described in this article.

\section{2- Methodology}


The glasses in Table 1 are prepared using a melt quenching technique, as reported in our published articles. By melting together specific weights of $\mathrm{B}_{2} \mathrm{O}_{3}$ in its $\mathrm{H}_{3} \mathrm{BO}_{4}$ (Merck), $\mathrm{NaF}$ in it (Aldrich), $\mathrm{La}_{2} \mathrm{O}_{3}$ in it (Merck), $\mathrm{BaO}$ and $\mathrm{PbO}$ in it (Merck) in an o pen ceramic crucible, glass samples were prepared with the formula $53 \mathrm{~B}_{2} \mathrm{O}_{3}-2 \mathrm{NaF}-27 \mathrm{PbO}-(20-x) \mathrm{BaO}-x \mathrm{La}_{2} \mathrm{O}_{3}$ $(0 \leq x \geq 15)$. With the evaporation of $\mathrm{H}_{2} \mathrm{O}, \mathrm{H}_{3} \mathrm{BO}_{4}$ are converted into $\mathrm{B}_{2} \mathrm{O}_{3}$ throughout melting in open ceramics crucibles. Thus, it is possible to estimate the required amount of oxide to match the chemical formula used by knowing the molecular weight of $\mathrm{H}_{3} \mathrm{BO}_{4}$, and $\mathrm{B}_{2} \mathrm{O}_{3}$. The porcelain crucible with the blend was kept at $650{ }^{\circ} \mathrm{C}$ for 30 minutes to decrease the tendency to volatilize. At the melting temperature $1200{ }^{\circ} \mathrm{C}$, the furnace temperature was modified. the melt the glass was cast a clean stainless-steel mold. These glass samples annealing at $400{ }^{\circ} \mathrm{C}$.

To verify the status of these glasses the Philips X-ray diffractometer (model PW / 1710) was used. Optical parameters were predictable by using spectrophotometer type JASCO, V-670 (Japan). DTA-50 For thermal investigation, (Shimadzu- Japan) was used. Phy-X / PSD, by Sakar et al. [23] can compute various shielding features. Beer-Lambert law $\mu=-\frac{\ln \frac{I}{I_{o}}}{x}$, . Where $\mu$ the linear attenuation coefficient $\left(\mathrm{cm}^{-1}\right) \mathrm{I}_{0}$ and I respectively. The mean free path (MFP) has been estimated as $M E P=\left(\frac{1}{\mu}\right)$,. Electron density $\left(\mathrm{N}_{\text {eff }}\right)$ has been estimated as: $\mathrm{N}_{\text {eff }}=\mathrm{N} \frac{\mathrm{Z}_{\mathrm{eff}}}{\sum_{\mathrm{i}} \mathrm{F}_{\mathrm{i}} \mathrm{A}_{\mathrm{i}}}$, . Effective cross-section of removal $\left(\Sigma_{\mathrm{R}}\right)$ predicted as: $\left(\frac{\Sigma_{\mathrm{R}}}{\rho}\right)=\sum_{\mathrm{i}} \mathrm{W}_{\mathrm{i}}\left(\frac{\Sigma_{\mathrm{R}}}{\rho}\right)_{\mathrm{i}}$ and $\mathrm{R}=\sum_{\mathrm{i}} \rho_{\mathrm{i}}\left(\frac{\mathrm{R}}{\rho}\right)_{\mathrm{i}}$,

\section{Results and Discussions}

\subsection{Optical characteristics}

There were no sharp peaks in the XRD in graph $\mathbf{1}$, indicating the high glass status of these samples. 
Figure 2, 3 exemplifies the absorption (A) and transmittance (T) and reflectance (R) of glass samples. It has been reported that spectral UV-absorption is increasingly absorbed. Therefore, $\mathrm{La}_{2} \mathrm{O}_{3}$ is accountable for the slight growth of $\mathrm{BO}$ [24-36]. Absorption coefficient of the glasses exemplifies Fig. 4.

\subsubsection{Direct and indirect energy gap Eopt}

Glass absorption spectrum in the ultraviolet and visible regions were used for the estimated of the band gap energy $E_{o p t}$ is estimated by $(\alpha \cdot h v)^{1 / 2}=B\left(h v-E_{\text {opt. }}\right)$ where B is an energy independent constant and $h v$ is photon energy. By plotting the $(\alpha . h v)^{1 / 2}$ versus $h v$ as Fig.5. Plot of $(\alpha . h v)^{1 / 2}$ against photon energy $(h v)$ to evaluate the indirect $E_{\text {opt }}$ from the intercept. $E_{\text {opt }}$ increases with increasing $\mathrm{La}_{2} \mathrm{O}_{3}$ content, as shown in Table 3, because of the formation of oxygen bridges (BO) that bind excited electrons more strongly than non-bridging oxygen electrons (NBO). Urbach energy $E_{u}$ of samples has been projected as $\propto_{0} \exp \left(\frac{h v}{E_{u}}\right)$, Fig. 6 and recorded in table 3, demonstrating that an opposing relation is noticed between their values of $E_{o p t}$. Fig.7 presented the values of $E_{o p t}$ and $E_{u}$.

\subsubsection{Refractive index (n)}

Refractive index of manufacturing glass ( $\mathrm{n}$ ) has been already computed as: $n=$ $\frac{(1-R)^{2}+k^{2}}{(1+R)^{2}+k^{2}} \quad$ where $k=\square \square / 4 \square .(n)$ of manufacturing glasses obtainable in Fig.8, it detected that $(n)$ of the investigated glasses are increases as density increase. It has been mentioned that a direct correlation between the density and refractive index, i.e., the denser the glass study, the greater the refractive index. So, the refractive index is exactly applicable to reflection and density, and the molar volume is inversely comparable.

\subsubsection{Dispersion parameters}


Molar polarization, and polarizability of samples were projected as $R_{m}=$ $\left\langle n^{2}-1 \mid n^{2}+2\right\rangle V m, \propto_{m}=(3 \mid 4 \pi N) R_{m}, \quad$ and $\quad \propto_{0}^{2-}=\frac{\left[\frac{V m}{2.52}\left(\frac{n^{2}-1}{n^{2}+2}\right)-\sum \propto_{c a t}\right]}{N_{o}^{2-}} . \quad$ The optical fundamentality of investigated glasses has been linked to polarization; $\Lambda=1.67\left(1-\frac{1}{\alpha_{0}^{2-}}\right)$. The molar polarizability, polarizability, and optical basicity of the glass under study were described in Figures 8,9\&10. The same refractive index trend with concentrations of $\mathrm{La}_{2} \mathrm{O}_{3}$ has been observed. With the alteration of density and refractive index indicating that the samples are more polarized because of the increase of $\mathrm{La}_{2} \mathrm{O}_{3}$, thus, the molar polarizability of glasses increases.

The molar refractivity as $E_{\text {opt. }} R_{m}=\operatorname{Vm}(1-\sqrt{E g / 20})$ and molar polarizability $\left(\propto_{m}\right)$ $\propto_{m}=\left(\frac{3}{4 \pi N}\right) R_{m}$. Reflection loss $R_{L}=\left(\frac{R_{m}}{V m}\right)$. These values of $\left(R_{m}\right)\left(\propto_{m}\right)$ and $\left(R_{L}\right)$ decrease with $\mathrm{La}_{2} \mathrm{O}_{3}$ because of the decrease in the molar volume are presented in Table 3 . The criterion for metallization is predicted as $M=1-\frac{R_{m}}{V m}$, the metallization value rise with $\mathrm{La}^{+3}$. The electronegativity $(\chi)$ is predicted as $\chi=0.2688 E_{\text {opt. }}$. where $E_{\text {opt }}$. bandgap. Thus, with $\mathrm{La}^{+3}$ increasing, the electronegativity $(\chi)$ values increase. The electron polarizability is predicted as, $\propto^{\circ}=-0.9 \chi+3.5$ and optical basicity $\wedge=-0.5 \chi+1.7 . \propto^{\circ}$ and $\wedge$ have the inverse value of $(\chi)$ thus, with $\mathrm{La}^{+3}$ increase $\alpha^{\circ}$ and $\wedge$ decrease. This explanation is linked to the value of the optical basicity of $\mathrm{La}_{2} \mathrm{O}_{3}$ (1.3149) and $\mathrm{BaO}$ s (1.23) [37-38]. Table 2 shows these values.

The bulk module $(\mathrm{K})$ and the temperature of the glass transition are directly related to $E_{\text {opt }}$ and projected as $K_{t h}=-478.93+200.13 E_{g}, T_{g(\text { thero. })}=-701.87+403.33 E_{g}$. Values $K_{\text {th }}$ and $T_{g(\text { thero.) }}$ in Table 3. It stated that, because of increase in bond strength, these values increase with $\mathrm{La}_{2} \mathrm{O}_{3}$. 
For $\mathrm{BO}$ or NBO connection confirmation, a significant parameter is the coordinated average number and is defined as $m=\sum n_{c i} X_{i}$ where cation coordination is $n_{c i}$. As the value in Table 2 it was originate that $m$ increased with the rise in $\mathrm{La}_{2} \mathrm{O}_{3}$ content.

The number of bonds per unit is calculated as $n_{b}=\frac{N_{A}}{V_{m}} \sum n_{c i} X_{i}$. As the value in Table 2 it was initiate that $n_{b}$ increased with the rise in $\mathrm{La}_{2} \mathrm{O}_{3}$ content. Clearly, it demonstrates the modifier character of $\mathrm{La}_{2} \mathrm{O}_{3}$ in the glass samples.

The factor of two-photon absorption TPA $(\beta) \mathrm{cm} / \mathrm{GW}$, expressed as $\beta=36.67-$ $8.1 E_{\text {opt }}$ where $E_{\text {opt }}$ bandgap energy. For solid-state physics, one of the most significant parameters is TPA. As the value in Table 3 it was originate that $(\beta)$ decreased with the increase in $\mathrm{La}_{2} \mathrm{O}_{3}$ content because of $E_{\text {opt }}$ increase.

The ionic and covalent character of glasses can be established as the electronegativity difference $\Delta X=\sum X_{i} \Delta X_{i}$, where $\Delta X_{i}=X_{O}-X_{M}, I_{b}=\left[1-e^{\left.(-0.25)\left(X^{2}\right)\right)}\right]$ where $I_{b}$ Ionicity. As the values in Table 3 it was found that $\left(I_{b}\right)$ decreased with the increase in $\mathrm{La}_{2} \mathrm{O}_{3}$ content and covalency $I_{C}$ increase.

A refractive index of Moss, Ravindra, Herve \& Vandmme, Reddy, Anani, Kumar \& Singh and Average (n) by direct and indirect bandgap was shown in figures $11 \& 12$ [39-44]. It observed that small deviation in the $(n)$ because of linear and non-linear bandgap. Dielectric, a

n

d

\subsection{Thermal analysis}

$\mathrm{t}$ The thermal behaviours of prepared glasses were characterized by DTA in the

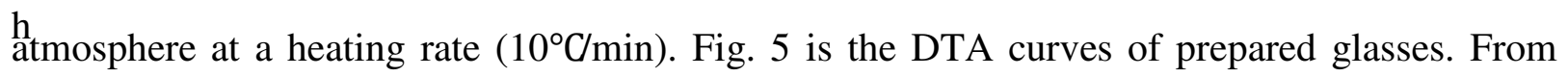
DTA curves Fig.13, it was noticed that the glass transition temperature $\mathrm{T}_{\mathrm{g}}$ increased with 
increasing $\mathrm{La}_{2} \mathrm{O}_{3}$, it increase from $421^{\circ} \mathrm{C}$ at $0 \%$ to $457^{\circ} \mathrm{C}$ at $15 \%$ as shown in Table 5 and Fig. 5 , the onset of crystallization temperature Tc increased with increasing $\mathrm{La}_{2} \mathrm{O}_{3}$, it increase from $455^{\circ} \mathrm{C}$ at $0 \%$ to $488^{\circ} \mathrm{C}$ at $15 \%$ as shown in Table 6 and Fig. 13 , the end-set of crystallization temperature $\mathrm{T}_{\mathrm{p}}$ increased with increasing $\mathrm{La}_{2} \mathrm{O}_{3}$, it increase from $494^{\circ} \mathrm{C}$ at $0 \%$ to $542^{\circ} \mathrm{C}$ at $15 \%$ as shown in Table 6 and Fig.13. This increases due to increase in the average force constantly, connectivity and increase in packing density.

Thermal stability projected by $\Delta T=T_{c}-T_{g}$, weighted thermal stability $H_{g}=\frac{\Delta T}{T_{g}}, \mathrm{~S}=$ $\left(T_{p}-T_{c}\right) \frac{\Delta T}{T_{g}}$. From Table 5 , it was noticed that the thermal stability of these glasses increased with the increase in $\mathrm{La}_{2} \mathrm{O}_{3}$ content. With the increase $\mathrm{La}_{2} \mathrm{O}_{3}$ at expense of $\mathrm{BaO}$ increase the creation of $\mathrm{BO}$, the stronger $\mathrm{La}-\mathrm{O}-\mathrm{B}$ bonds formation and the bond strength of $\mathrm{La}-\mathrm{La}$ (58kcals) is stronger than bond strength of $\mathrm{Ba}-\mathrm{Ba}$ (33kcals) [45].

\subsection{Radiation shielding Properties.}

This research examined the degree of shielding [46-54] from increase $\mathrm{La}_{2} \mathrm{O}_{3}$ at the expense of $\mathrm{BaO}$ with a nominal composition of $53 \mathrm{~B}_{2} \mathrm{O}_{3}-2 \mathrm{NaF}-27 \mathrm{PbO}-(20-x) \mathrm{BaO}-$ $x \mathrm{La}_{2} \mathrm{O}_{3} \quad(0 \leq x \geq 15)$. The mean free path (MFP) was projected as $M E P=\left(\frac{1}{\mu}\right)$, and shown in Fig. 14. It noticed that, as the photon energy and the $\mathrm{La}_{2} \mathrm{O}_{3}$ content increase the values of (MFP) increase. This motivation discloses that the rise in energy makes the photon capable of purposely transmitting samples. From this Fig. 14 shows that, the lower value of (MFP) is sample contain higher content of $\mathrm{La}_{2} \mathrm{O}_{3}$ therefore it is better samples for attenuation of $\gamma$ radiation. Fig.15 presented (MFP) of glasses comparison with standard materials.

Fig. 16 represented the $\left(N_{\text {eff }}\right)$ values of samples against energy. It is indicated that $\left(N_{\text {eff }}\right)$ decreases with the increase of the energy and then gradually increase. The Compton scattering interaction is responsible for this decrease. The increase in $\left(N_{\text {eff }}\right)$ is related to the pair creation 
effect at higher energy and an increase in the content of $\mathrm{La}_{2} \mathrm{O}_{3}$. Thus, at the expense of $\mathrm{BaO}$, the emergence of $\mathrm{La}_{2} \mathrm{O}_{5}$ leads to a better in $\gamma$-radiation.

Fig. $17 \& 18$ represented the $A S C$ and, ESC of glass samples against the photon energy. It is suggested that, with the increase in energy, the $A S C$ and $E S C$ values are decreased. This decreases due to the Compton scattering interaction. Fig. 19 represented the $C_{e f f}$ of the prepared samples against the gamma energy. It is proposed that with the rise the photon energy, the $C_{\text {eff }}$ will decrease, then increasing gradually. This decreases because of the presence of the Compton scattering. The increase of $\left(C_{e f f}\right)$ correlated to the higher-energy pair-creation effect and increased in $\mathrm{La}_{2} \mathrm{O}_{3}$ content.

Cross-through effective removal $(\Sigma R)$ designated that the neutron particle crosses the material does not any interaction. ( $\Sigma R)$ of investigated glasses with energy characterized in Fig. 20. It is confirmed that at lower energy, the almost $(\Sigma R)$ increased. Small deviations of glass samples with a decrease in the value of $(\Sigma R)$ are observed at higher energy. These deviations are linked to the increase of $\mathrm{La}_{2} \mathrm{O}_{3}$. It is well known that elements that have a light atomic number have a strong ability to protect the neutrons. The increase in the content of $\mathrm{La}_{2} \mathrm{O}_{3}$, enhances the shielding of neutrons.

Fast neutron removal cross-section (FNRCS) is shown in Fig. 21. It noted that FNRCS increased with $\mathrm{La}_{2} \mathrm{O}_{3}$. We can say that the addition of $\mathrm{La}_{2} \mathrm{O}_{3}$ to glass samples enhances the FNRCS.

\section{Conclusions}

Glasses with the chemical formula $53 \mathrm{~B}_{2} \mathrm{O}_{3}-2 \mathrm{NaF}-27 \mathrm{PbO}-(20-x) \mathrm{BaO}-x \mathrm{La}_{2} \mathrm{O}_{3}$ $(0 \leq x \geq 15)$ have been manufactured successfully with the technique of traditional meltquenching and their radiation, thermal and optical properties have been studied. The XRD diffractometer technique was implemented to check the structure of glasses. The thermal properties of glasses are dependent on the structure and these characteristics were identified to 
increase with an increase in $\mathrm{La}_{2} \mathrm{O}_{3}$ content. The addition of $\mathrm{La}_{2} \mathrm{O}_{3}$ to the glasses enhanced physical properties. A refractive index is obtained by direct and indirect bandgap from Moss, Ravindra, Herve \& Vandmme, Reddy, Anani, Kumar \& Singh and Average (n). Multiple parameters of optics $\left(\square^{\infty}\right),\left(\square_{0}\right), \chi^{(1)},\left(\chi^{(3)}\right)$ and $\left(n_{2}\right)$ as a function of linear and non-linear $E_{\text {opt }}$ were obtained. Theoretically, due to the increase in bond strength, the bulk modulus and glass transition temperature increase. The number of bonds per unit increased with the increase in $\mathrm{La}_{2} \mathrm{O}_{3}$ content because of the modifier character $\mathrm{La}_{2} \mathrm{O}_{3}$ in the glass samples. The degree of shielding in this paper was investigated from increase $\mathrm{La}_{2} \mathrm{O}_{3}$ at the expense of $\mathrm{BaO}$. The lower value of (MFP) is higher content $\mathrm{La}_{2} \mathrm{O}_{3}$ therefore it is better samples for attenuation of $\gamma$ radiation. $\left(N_{\text {eff }}\right)$ decreases with the increase of the energy due to the Compton scattering interaction and then gradually increase due to the pair creation effect at higher energy and an increase in the content of $\mathrm{La}_{2} \mathrm{O}_{3} . A S C, E S C, C_{\text {eff, }}$ and $(\Sigma R)$ are obtained. FNRCS increased with $\mathrm{La}_{2} \mathrm{O}_{3}$. The $\gamma$-ray and fast neutron radiation-shielding abilities of glass samples were investigated. Therefore, the glass composition $53 \mathrm{~B}_{2} \mathrm{O}_{3}-2 \mathrm{NaF}-27 \mathrm{PbO}-5 \mathrm{BaO}-15 \mathrm{La}_{2} \mathrm{O}_{3}$ is the best candidate for photon shielding applications. Obtaining the physical, and optical values of these glasses can help develop multiple equipment and innovations, including batteries with solid state and gamma ray's protection. The results correspond with similar studies conducted previously. 
Author contributions: Kh. S. Shaaban: performing XRD, UV measurements and analysis, Writing-review, writing manuscript, Methodology, Software, and writing - discussion.

Acknowledgments: There is no yet.

Availability of data and material: My manuscript and associated personal data will be shared with Research Square for the delivery of the author dashboard.

Compliance with ethical standards: The manuscript has not been published elsewhere and that it has not been submitted simultaneously for publication elsewhere.

Conflict of interest: The authors declare that they have no conflict of interest.

Declaration of Competing Interest: The authors declare that they have no known competing financial interests or personal relationships that could have appeared to influence the work reported in this paper

Funding statement: There is no funding. 


\section{References}

[1] Shakespeare, W. (2002). Halide Glass. Structural Chemistry of Glasses, 1-12. doi:10.1016/b978-008043958-7/50019-4

[2] Yamane, M., Kawazoe, H., Inoue, S., \& Maeda, K. (1985). IR transparency of the glass of $\mathrm{ZnCl}_{2}-\mathrm{KBr}-\mathrm{PbBr}_{2}$ system. Materials Research Bulletin, 20(8), 905-911. doi:10.1016/00255408(85)90073-X

[3] El-Rehim, A.F.A., Shaaban, K.S. (2021). Influence of $\mathrm{La}_{2} \mathrm{O}_{3}$ content on the structural, mechanical, and radiation-shielding properties of sodium fluoro lead barium borate glasses. J Mater Sci: Mater Electron, https://doi.org/10.1007/s10854-020-05204-7

[4] Shaaban, K.S., Saddeek, Y.B., Sayed, M.A. et al. (2018). Mechanical and Thermal Properties of Lead Borate Glasses Containing $\mathrm{CaO}$ and NaF. Silicon 10, 1973-1978. https://doi.org/10.1007/s12633-017-9709-8

[5] Okasha A, Marzouk SY, Hammad AH, Abdelghany AM (2017). Optical character inquest of cobalt containing fluoroborate glass. Optik - Int J Light Electron Opt 142:125-133 https://doi.org/10.1016/j.ijleo.2017.05.088

[6] Wong J, Angell CA (1976) Glass structure by Spectroscopy. Maral Dekker Inc., New York

[7] Schuyt, J. J., \& Williams, G. V. M. (2020). Photoluminescence of $\mathrm{Dy}^{3+}$ and $\mathrm{Dy}^{2+}$ in $\mathrm{NaMgF}_{3}$ : Dy: A potential infrared radio photoluminescence dosimeter. Radiation Measurements, 106326. doi: 10.1016/j.radmeas.2020.106326

[8] Elbatal, F. H. A., Marzouk, M. A., Hamdy, Y. M., \& ElBatal, H. A. (2014). Optical and FT Infrared Absorption Spectra of 3d Transition Metal Ions Doped in $\mathrm{NaF}-\mathrm{CaF}_{2}-\mathrm{B}_{2} \mathrm{O}_{3}$ Glass and Effects of Gamma Irradiation. Journal of Solid-State Physics, 2014, 1-8. doi:10.1155/2014/389543 
[9] Doweidar, H., El-Damrawi, G., \& Abdelghany, M. (2012). Structure and properties of $\mathrm{CaF}_{2}-\mathrm{B}_{2} \mathrm{O}_{3}$ glasses. Journal of Materials Science, 47(9), 4028-4035. doi:10.1007/s10853-0126256-y

[10] Abdelghany, A. M., ElBatal, H. A., \& EzzElDin, F. M. (2015). Influence of CuO content on the structure of lithium fluoroborate glasses: Spectral and gamma irradiation studies. Spectrochimica Acta Part A: Molecular and Biomolecular Spectroscopy, 149, 788-792. doi: 10.1016/j.saa.2015.04.105

[11] Yadav, A., Dahiya, M. S., Narwal, P., Hooda, A., Agarwal, A., \& Khasa, S. (2017). Electrical characterization of lithium bismuth borate glasses containing cobalt/vanadium ions. Solid State Ionics, 312, 21-31, doi: 10.1016/j.ssi.2017.10.006

[12] Shaaban, K.S., Yousef, E.S., Abdel Wahab, E.A. et al. (2020). Investigation of Crystallization and Mechanical Characteristics of Glass and Glass-Ceramic with the Compositions $x \mathrm{Fe}_{2} \mathrm{O}_{3}-35 \mathrm{SiO}_{2}-35 \mathrm{~B}_{2} \mathrm{O}_{3}-10 \mathrm{Al}_{2} \mathrm{O}_{3}-(20-x) \quad \mathrm{Na}_{2} \mathrm{O} J$. of Materi Eng and Perform 29, 4549-4558 https://doi.org/10.1007/s11665-020-04969-6

[13] Shaaban, K.S., Abo-Naf, S.M. \& Hassouna, M.E.M. Physical and Structural Properties of Lithium Borate Glasses Containing $\mathrm{MoO}_{3}$. Silicon 11, 2421-2428 (2019). https://doi.org/10.1007/s12633-016-9519-4

[14] Abd-Allah, W.M., Saudi, H.A., Shaaban, K.S. et al. Investigation of structural and radiation shielding properties of $40 \mathrm{~B}_{2} \mathrm{O}_{3}-30 \mathrm{PbO}-(30-x) \mathrm{BaO}-x \mathrm{ZnO}$ glass system. Appl. Phys. A 125, 275 (2019). https://doi.org/10.1007/s00339-019-2574-0

[15] Shaaban, K. S., Abo-naf S. M., Abd Elnaeim, A. M., \& Hassouna, M. E. M. Studying effect of $\mathrm{MoO}_{3}$ on elastic and crystallization behavior of lithium diborate glasses. Applied Physics A, 123(6), (2017). doi:10.1007/s00339-017-1052-9 
[16] Wahab, E. A. A., \& Shaaban, K. S. Effects of $\mathrm{SnO}_{2}$ on spectroscopic properties of borosilicate glasses before and after plasma treatment and its mechanical properties. Materials Research Express, 5(2), 025207, (2018). doi:10.1088/2053-1591/aaaee8

[17] El-Rehim, A.F.A., Ali, A.M., Zahran, H.Y.et al. (2020). Spectroscopic, Structural, Thermal, and Mechanical Properties of $\mathrm{B}_{2} \mathrm{O}_{3}-\mathrm{CeO}_{2}-\mathrm{PbO}_{2}$ Glasses. J Inorg Organomet Polym https://doi.org/10.1007/s10904-020-01799-w

[18] Shaaban, K. S., El Sayed Yousef. Optical properties of $\mathrm{Bi}_{2} \mathrm{O}_{3}$ doped boro tellurite glasses and glass ceramics. Optik - International Journal for Light and Electron Optics 203, (2020), 163976. https://doi.org/10.1016/j.ijleo.2019.163976

[19] Abdel Wahab, E.A., Shaaban, K.S., Elsaman, R. et al. Radiation shielding, and physical properties of lead borate glass doped $\mathrm{ZrO}_{2}$ nanoparticles. Appl. Phys. A 125, 869 (2019). https://doi.org/10.1007/s00339-019-3166-8

[20] Shaaban, K.S., Yousef, E.S., Mahmoud, S.A. et al. (2020). Mechanical, Structural and Crystallization Properties in Titanate Doped Phosphate Glasses. J Inorg Organomet. Polym https://doi.org/10.1007/s10904-020-01574-X

[21] Kassab, L. R. P., Courrol, L. C., Seragioli, R., Wetter, N. U., Tatumi, S. H., \& Gomes, L. (2004). $\mathrm{Er}^{3+}$ laser transition in $\mathrm{PbO}-\mathrm{PbF}_{2}-\mathrm{B}_{2} \mathrm{O}_{3}$ glasses. Journal of Non-Crystalline Solids, 348, 94-97. doi: 10.1016/j.jnoncrysol.2004.08.132

[22] Ibrahim, S., ElBatal, F. H., \& Abdelghany, A. M. (2016). Optical character enrichment of $\mathrm{NdF}_{3}$ - doped lithium fluoroborate glasses. Journal of Non-Crystalline Solids, 453, 16-22. doi: 10.1016/j.jnoncrysol.2016.09.017

[23] Şakar, E., Özpolat, Ö. F., Alım, B., Sayyed, M. I., \& Kurudirek, M. (2020). Phy-X / PSD: Development of a user-friendly online software for calculation of parameters relevant to radiation shielding and dosimetry. Radiation Physics and Chemistry, 108496. doi: 10.1016/j.radphyschem.2019.108496 
[24] Shaaban, K.S., Wahab, E.A.A., Shaaban, E.R. et al. (2020). Electronic polarizability, optical basicity and mechanical properties of aluminum lead phosphate glasses. Opt Quant Electron 52, 125 https://doi.org/10.1007/s11082-020-2191-3

[25] Abdel-Baki, M., El-Diasty, F., \& Wahab, F. A. A. (2006). Optical characterization of $\mathrm{xTiO}_{2}-(60-\mathrm{x}) \mathrm{SiO}_{2}-40 \mathrm{Na}_{2} \mathrm{O}$ glasses: II. Absorption edge, Fermi level, electronic polarizability, and optical basicity. Optics Communications, 261(1), 65-70. doi: 10.1016/j.optcom.2005.11.056

[26] Shaaban, K.S., Koubisy, M.S.I., Zahran, H.Y. et al. Spectroscopic Properties, Electronic Polarizability, and Optical Basicity of Titanium-Cadmium Tellurite Glasses Doped with Different Amounts of Lanthanum. J Inorg Organomet Polym (2020). https://doi.org/10.1007/s10904-020-01640-4

[27] Somaily, H.H., Shaaban, K.S., Makhlouf, S.A. et al. Comparative Studies on Polarizability, Optical Basicity and Optical Properties of Lead Borosilicate Modified with Titania. J Inorg Organomet Polym (2020). https://doi.org/10.1007/s10904-020-01650-2

[28] Shaaban, K., Abdel Wahab, E.A., El-Maaref, A.A. et al. Judd-Ofelt analysis and physical properties of erbium modified cadmium lithium gadolinium silicate glasses. J Mater Sci: Mater Electron 31, 4986-4996 (2020). https://doi.org/10.1007/s10854-020-03065-8

[29] Fayad, A.M., Shaaban, K.S., Abd-Allah, W.M. et al. (2020). Structural and Optical Study of $\mathrm{CoO}$ Doping in Borophosphate Host Glass and Effect of Gamma Irradiation. J Inorg Organomet Polym https://doi.org/10.1007/s10904-020-01641-3

[30] Saudi, H.A., Abd-Allah, W.M. \& Shaaban, K.S. (2020). Investigation of gamma and neutron shielding parameters for borosilicate glasses doped europium oxide for the immobilization of radioactive waste. J Mater Sci: Mater Electron 31, 6963-6976 https://doi.org/10.1007/s10854-020-03261-6 
[31] Shaaban, K.S., Wahab, E.A.A., Shaaban, E.R. et al. Electronic Polarizability, Optical Basicity, Thermal, Mechanical and Optical Investigations of $\left(65 \mathrm{~B}_{2} \mathrm{O}_{3}-30 \mathrm{Li}_{2} \mathrm{O}-5 \mathrm{Al}_{2} \mathrm{O}_{3}\right)$ Glasses Doped with Titanate. Journal of Elec Materi 49, 2040-2049 (2020).

https://doi.org/10.1007/s11664-019-07889-x

[32] El-Rehim, A.F.A., Ali, A.M., Zahran, H.Y. et al. (2020). Spectroscopic, Structural, Thermal, and Mechanical Properties of $\mathrm{B}_{2} \mathrm{O}_{3}-\mathrm{CeO}_{2}-\mathrm{PbO}_{2}$ Glasses. J Inorg Organomet Polym https://doi.org/10.1007/s10904-020-01799-w

[33] Abdelghany, A. M., \& ElBatal, H. A. (2016). Optical and $\mu$-FTIR mapping: A new approach for structural evaluation of $\mathrm{V}_{2} \mathrm{O}_{5}$-lithium fluoroborate glasses. Materials \& Design, 89, 568-572. doi: 10.1016/j.matdes.2015.09.159

[34] El-Maaref, A. A., Wahab, E. A. A., Shaaban, K. S., Abdelawwad, M., Koubisy, M. S. I., Börcsök, J., \& Yousef, E. S. (2020). Visible and mid-infrared spectral emissions and radiative rates calculations of $\mathrm{Tm}^{3+}$ doped BBLC glass. Spectrochimica Acta Part A: Molecular and Biomolecular Spectroscopy,242, 118774. doi: 10.1016/j.saa.2020.118774

[35] Abdel Wahab, E.A., Shaaban, K.S. \& Yousef, E.S. (2020), Enhancement of optical and mechanical properties of sodium silicate glasses using zirconia. Opt Quant Electron 52, 458. https://doi.org/10.1007/s11082-020-02575-3

[36] E.A. Abdel Wahab, Novel borosilicate glass system: $\mathrm{Na}_{2} \mathrm{~B}_{4} \mathrm{O}_{7}-\mathrm{SiO}_{2}-\mathrm{MnO}_{2}$ : Synthesis, average electronics polarizability, optical basicity, and gamma-ray shielding features. Journal of Non-Crystalline Solids, https://doi.org/10.1016/j.jnoncrysol.2020.120509

[37] Zhao, X., Wang, X., Lin, H., \& Wang, Z. (2007). Electronic polarizability and optical basicity of lanthanide oxides. Physica B: Condensed Matter, 392(1-2), 132-136. doi: 10.1016/j.physb.2006.11.015 
[38] Dimitrov, V., \& Sakka, S. (1996). Electronic oxide polarizability and optical basicity of simple oxides. I. Journal of Applied Physics, 79(3), 1736-1740. doi:10.1063/1.360962

[39] Moss, T. S. (1985). Relations between the Refractive Index and Energy Gap of Semiconductors. Physica Status Solidi (b), 131(2), 415-427. doi:10.1002/pssb.2221310202 [40] Ravindra, N. M. (1981). Energy gap-refractive index relation — some observations. Infrared Physics, 21(5), 283-285. doi:10.1016/0020-0891(81)90033-6

[41] Gupta, V. P., \& Ravindra, N. M. (1980). Comments on the Moss Formula. Physica Status Solidi (b), 100(2), 715-719. doi:10.1002/pssb.2221000240

[42] Anani M., Mathieu C., Lebid S., Amar Y., Chama Z. and Abid H., (2008). Model for calculating the refractive index of a III-V semiconductor, Comput. Mater. Sci 41, 570-757, [43] Kumar V. and Singh J. K., (2010). Model for calculating the refractive index of different materials, Ind. J. Pure and Appl. Phys., 48, 571- 574,

[44] Hervé, P., \& Vandamme, L. K. J. (1994). General relation between refractive index and energy gap in semiconductors. Infrared Physics \& Technology, 35(4), 609-615. doi:10.1016/1350-4495(94)90026-4

[45] Varshneya Arun K., Fundamentals of inorganic glasses, Academic Prese Limited, (1994), p.33.

[46] Shaaban, K.S., Zahran, H.Y., Yahia, I.S. et al. (2020). Mechanical and radiation-shielding properties of $\mathrm{B}_{2} \mathrm{O}_{3}-\mathrm{P}_{2} \mathrm{O}_{5}-\mathrm{Li}_{2} \mathrm{O}-\mathrm{MoO}_{3}$ glasses. Appl. Phys. A 126, 804 https://doi.org/10.1007/s00339-020-03982-9

[47] Abdel Wahab, E.A., Shaaban, K.S., Elsaman, R. et al. (2019). Radiation shielding, and physical properties of lead borate glass doped $\mathrm{ZrO}_{2}$ nanoparticles. Appl. Phys. A (12) 125, 869 https://doi.org/10.1007/s00339-019-3166-8 
[48] El-Sharkawy, R. M., Shaaban, K. S., Elsaman, R., Allam, E. A., El-Taher, A., \& Mahmoud, M. E. (2020), Investigation of mechanical and radiation shielding characteristics of novel glass systems with the composition $\mathrm{xNiO}-20 \mathrm{ZnO}-60 \mathrm{~B}_{2} \mathrm{O}_{3}-(20-\mathrm{x}) \mathrm{CdO}$ based on nano metal oxides. Journal of Non-Crystalline Solids, 528,119754, DOI: 10.1016/j.jnoncrysol.2020. [49] El-Rehim, A.F.A., Zahran, H.Y., Yahia, I.S. et al. (2020) Physical, Radiation Shielding and Crystallization Properties of $\mathrm{Na}_{2} \mathrm{O}-\mathrm{Bi}_{2} \mathrm{O}_{3}{ }^{-} \quad \mathrm{MoO}_{3}-\mathrm{B}_{2} \mathrm{O}_{3^{-}} \quad \mathrm{SiO}_{2-}$ $\mathrm{Fe}_{2} \mathrm{O}_{3}$ Glasses. Silicon. https://doi.org/10.1007/s12633-020-00827-1

[50] El-Rehim, A.A., Zahran, H., Yahia, I. et al. (2020) Radiation, Crystallization, and Physical Properties of Cadmium Borate Glasses. Silicon. https://doi.org/10.1007/s12633-020-00798-3 [51] Kavaz, E., \& Yorgun, N. Y. Gamma ray buildup factors of lithium borate glasses doped with minerals. Journal of Alloys and Compounds, 752, (2018), 61-67. doi: $\underline{10.1016 / \text { j.ceramint.2019.05.028 }}$

[52] Kaur, P., Singh, D., \& Singh, T. (2016) Heavy metal oxide glasses as gamma rays shielding material. Nuclear Engineering and Design, 307, 364-376. doi: 10.1016/j.nucengdes.2016.07.029

[53] Ozturk, S., Ilik, E., Kilic, G. et al. (2020). Ta2 $\mathrm{O}_{5}$-doped zinc-borate glasses: physical, structural, optical, thermal, and radiation shielding properties. Appl. Phys. A 126, 844 https://doi.org/10.1007/s00339-020-04041-z

[54] Rammah, Y. S., Mahmoud, K. A., Kavaz, E., Kumar, A., \& El-Agawany, F. I. (2020). The role of $\mathrm{PbO} / \mathrm{Bi}_{2} \mathrm{O}_{3}$ insertion on the shielding characteristics of novel borate glasses. Ceramics International. 46, (15), 23357-23368 doi: 10.1016/j.ceramint.2020.04.018 
Figures

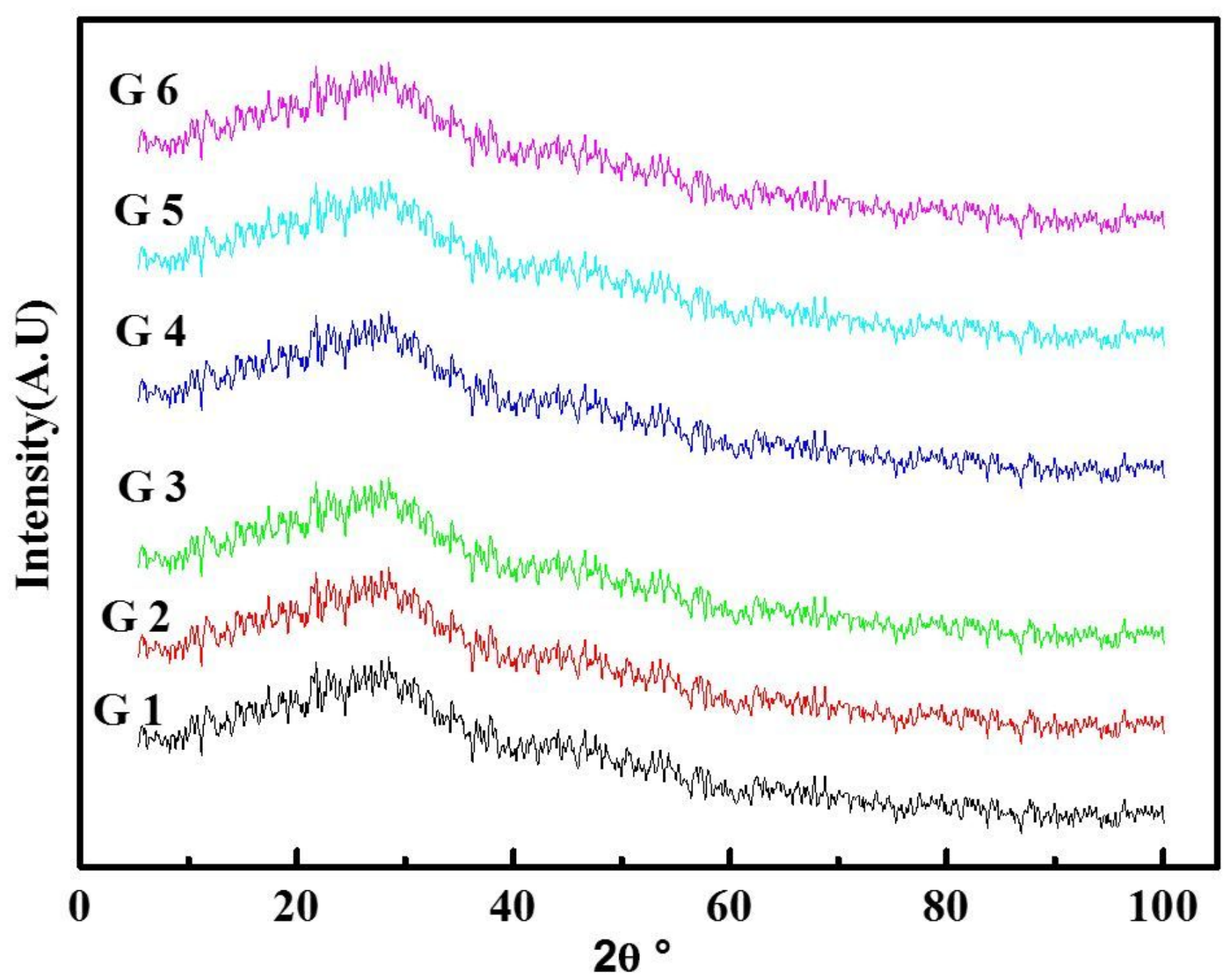

Figure 1

XRD of the studied glasses. 


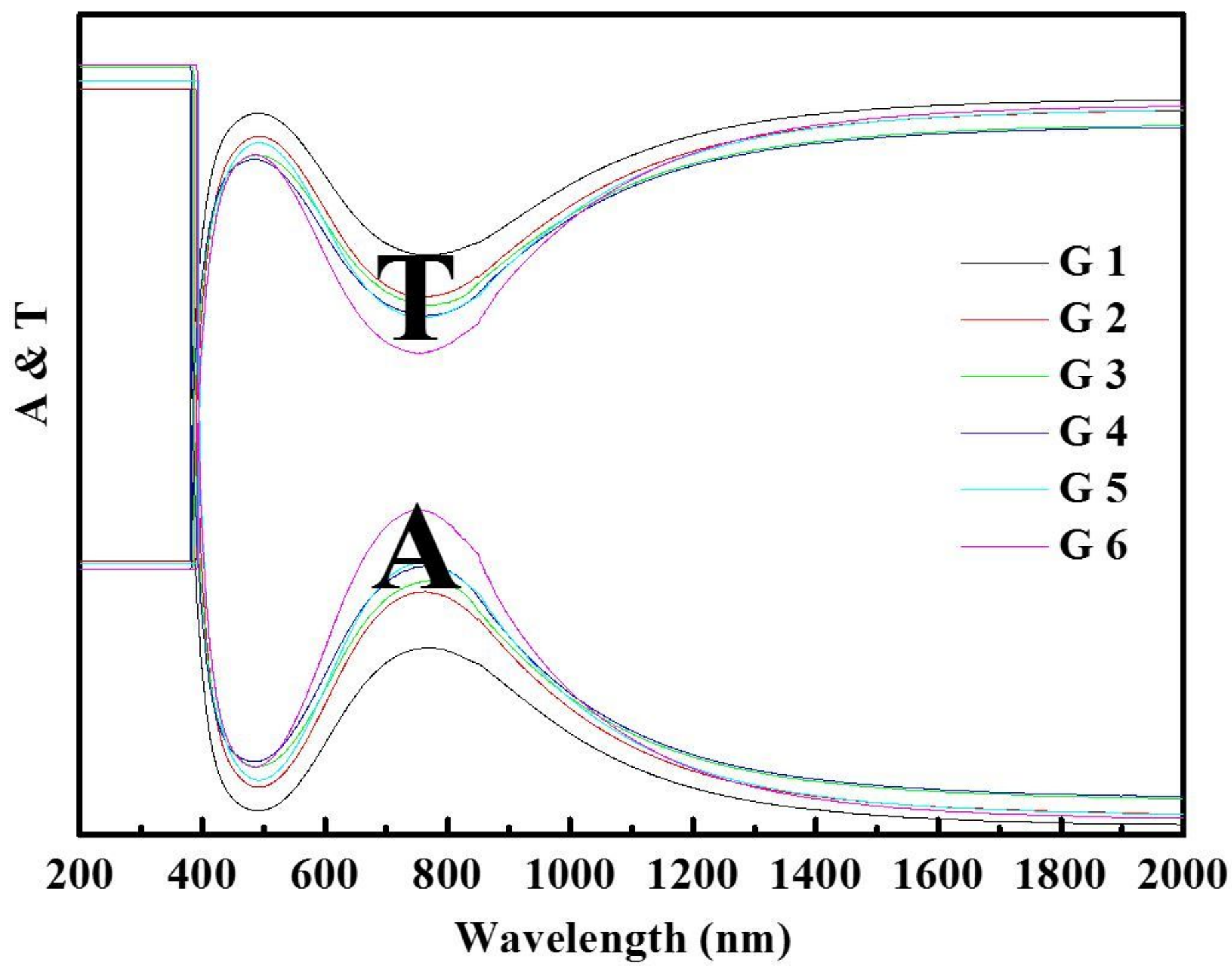

Figure 2

The absorbance (A) and transmittance $(T)$ of the prepared glasses. 


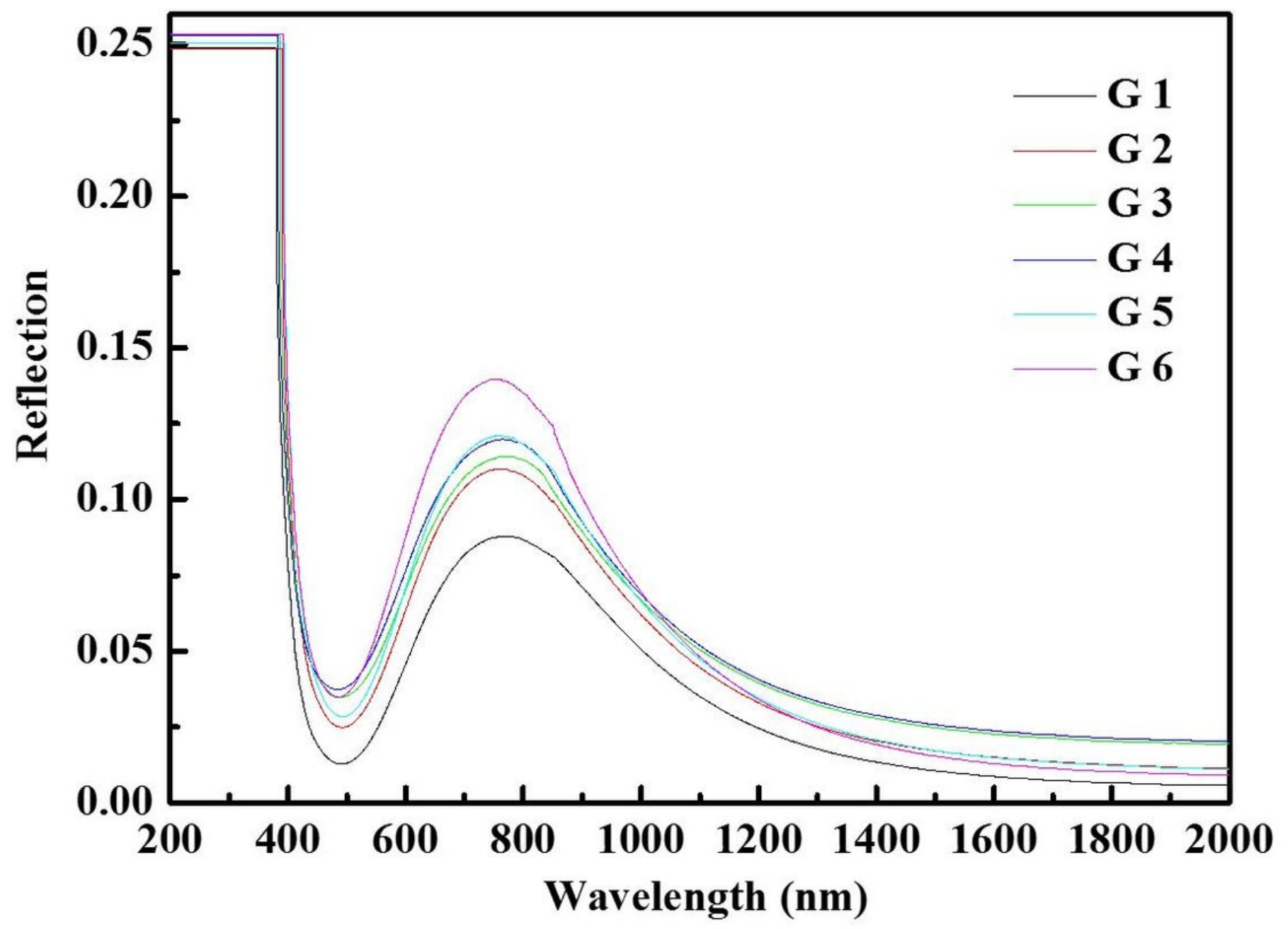

Figure 3

The reflections $(R)$ of the prepared glasses. 


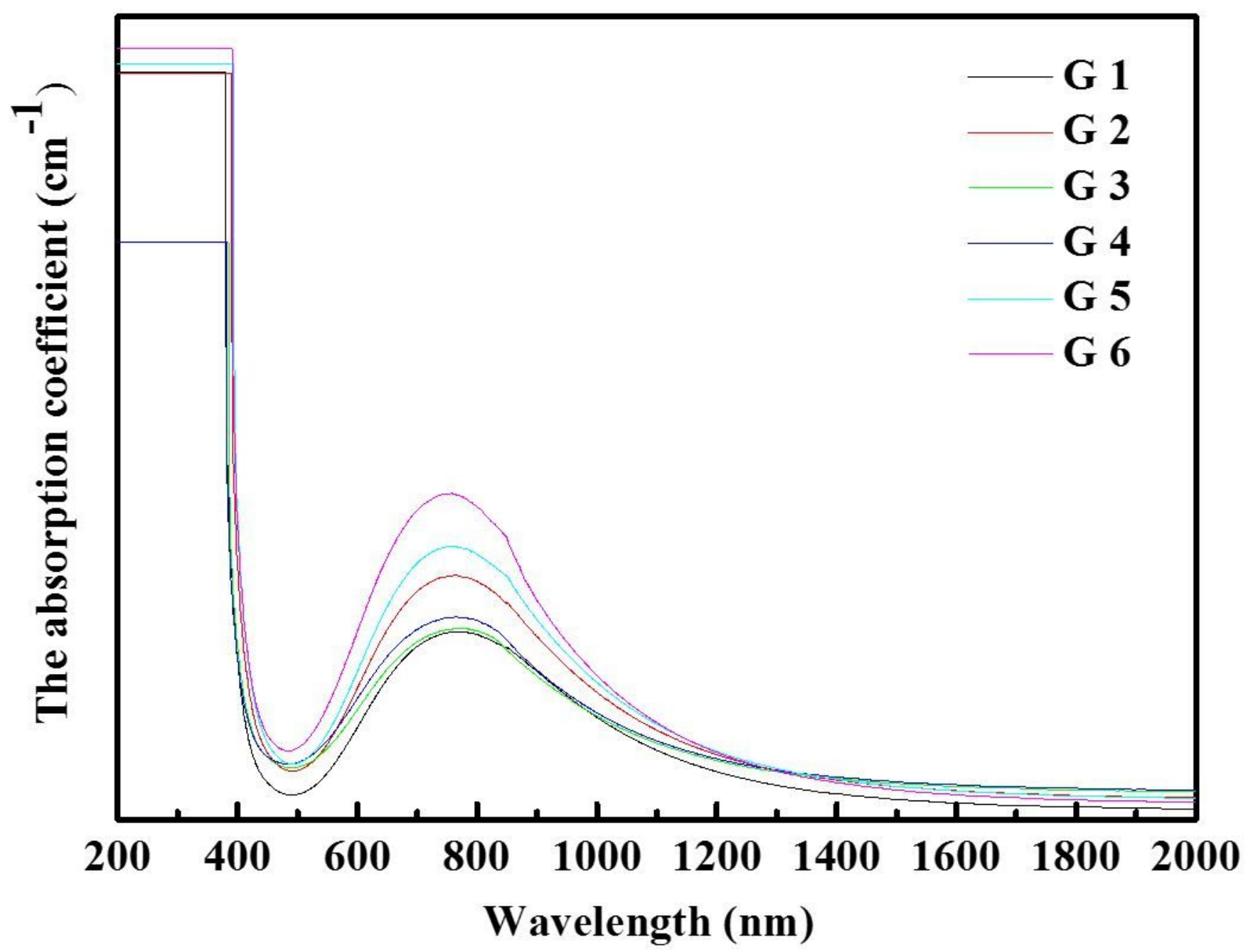

Figure 4

The absorption coefficient of the prepared glasses.
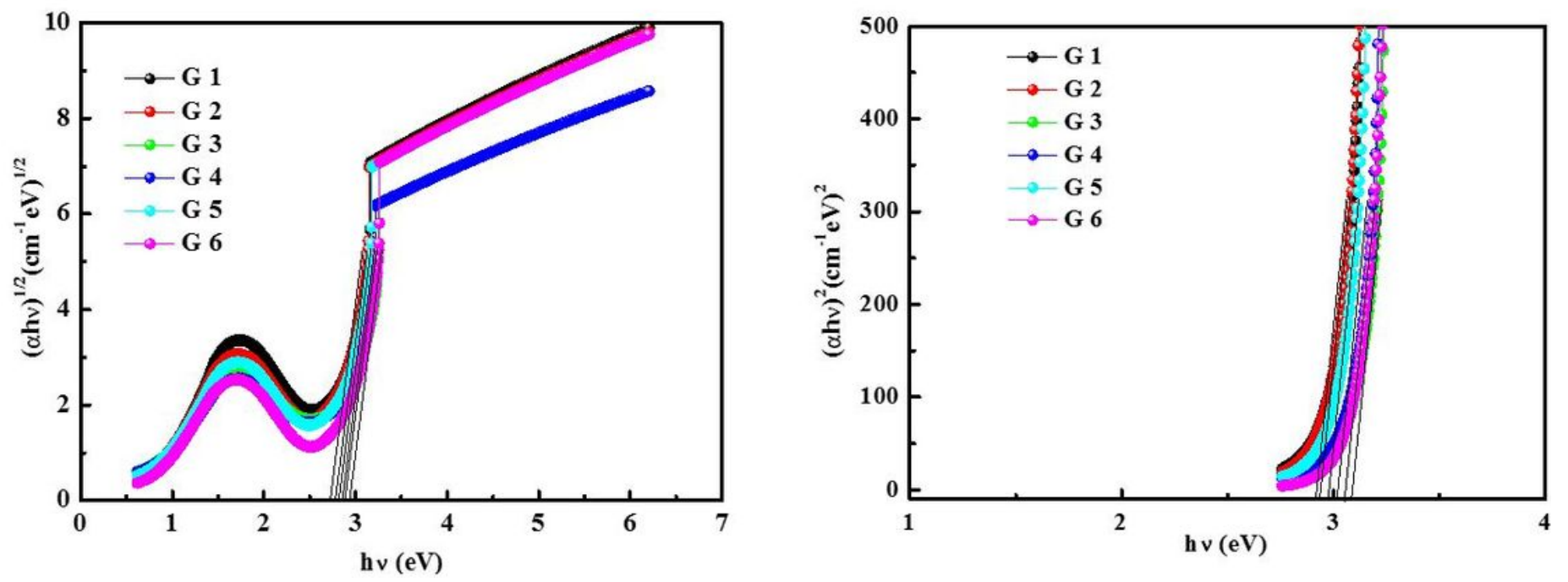

Figure 5 
a: Plot of (a hv)1/2 against photon energy (hv) to calculate the direct optical band gap from the intercept of the curves. b: Plot of ( $a$ hv) 2 against photon energy (hv) to calculate indirect optical band gap from the intercept of the curves.

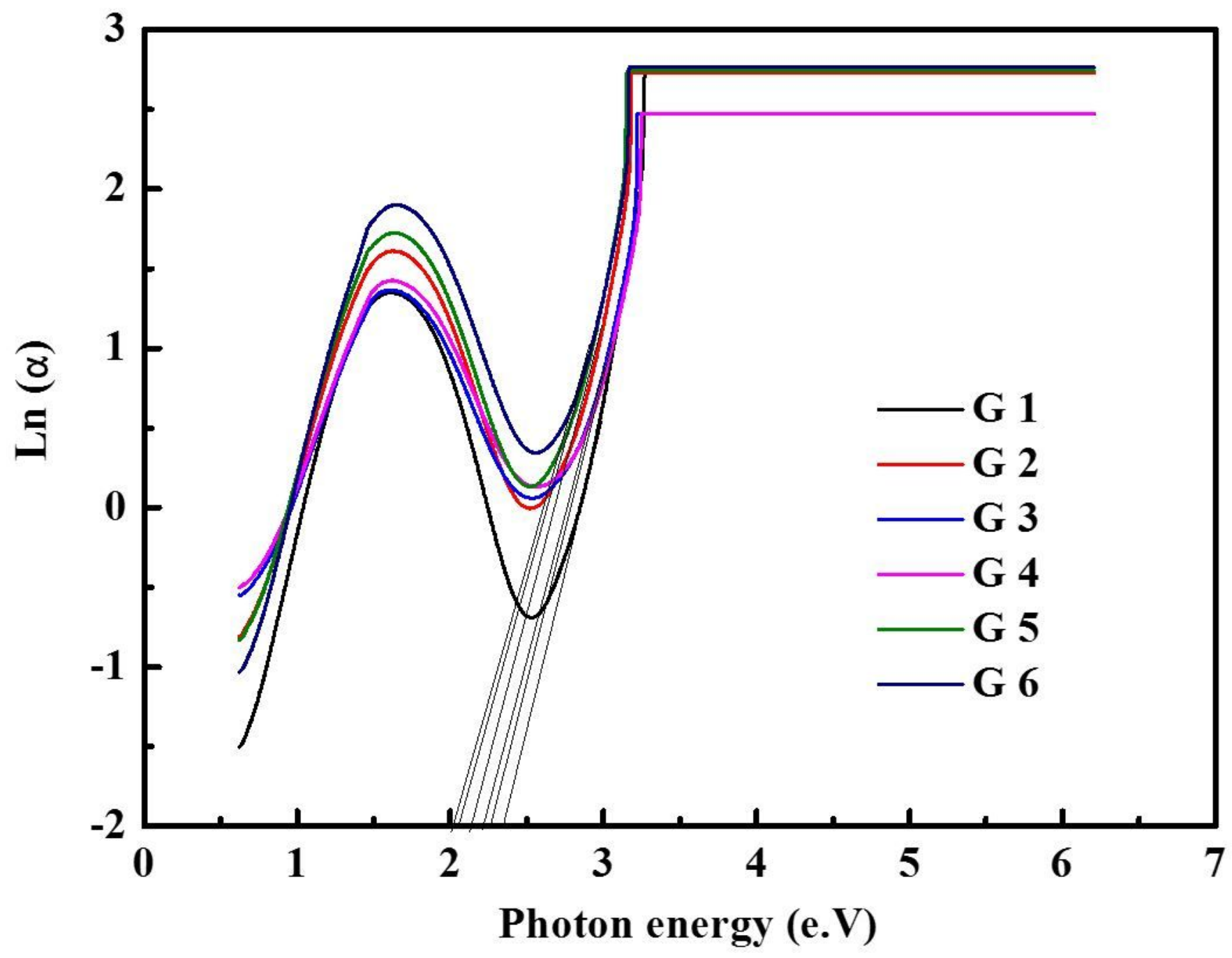

Figure 6

Dependence of $\ln (\mathrm{a})$ upon the photon energy (hu) for the prepared glasses. 


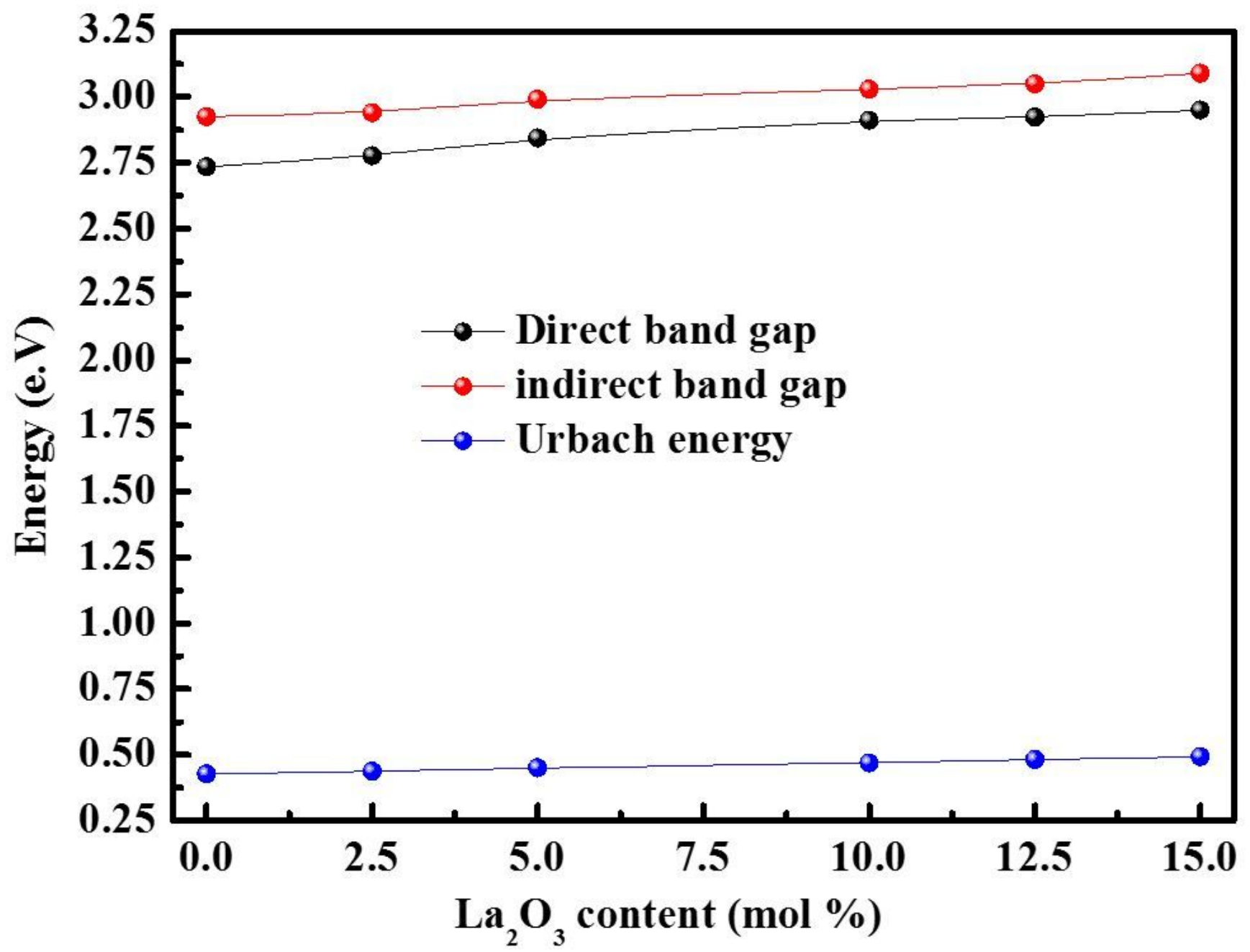

Figure 7

Dependence all energies as a function of La2O3 for the prepared glasses. 


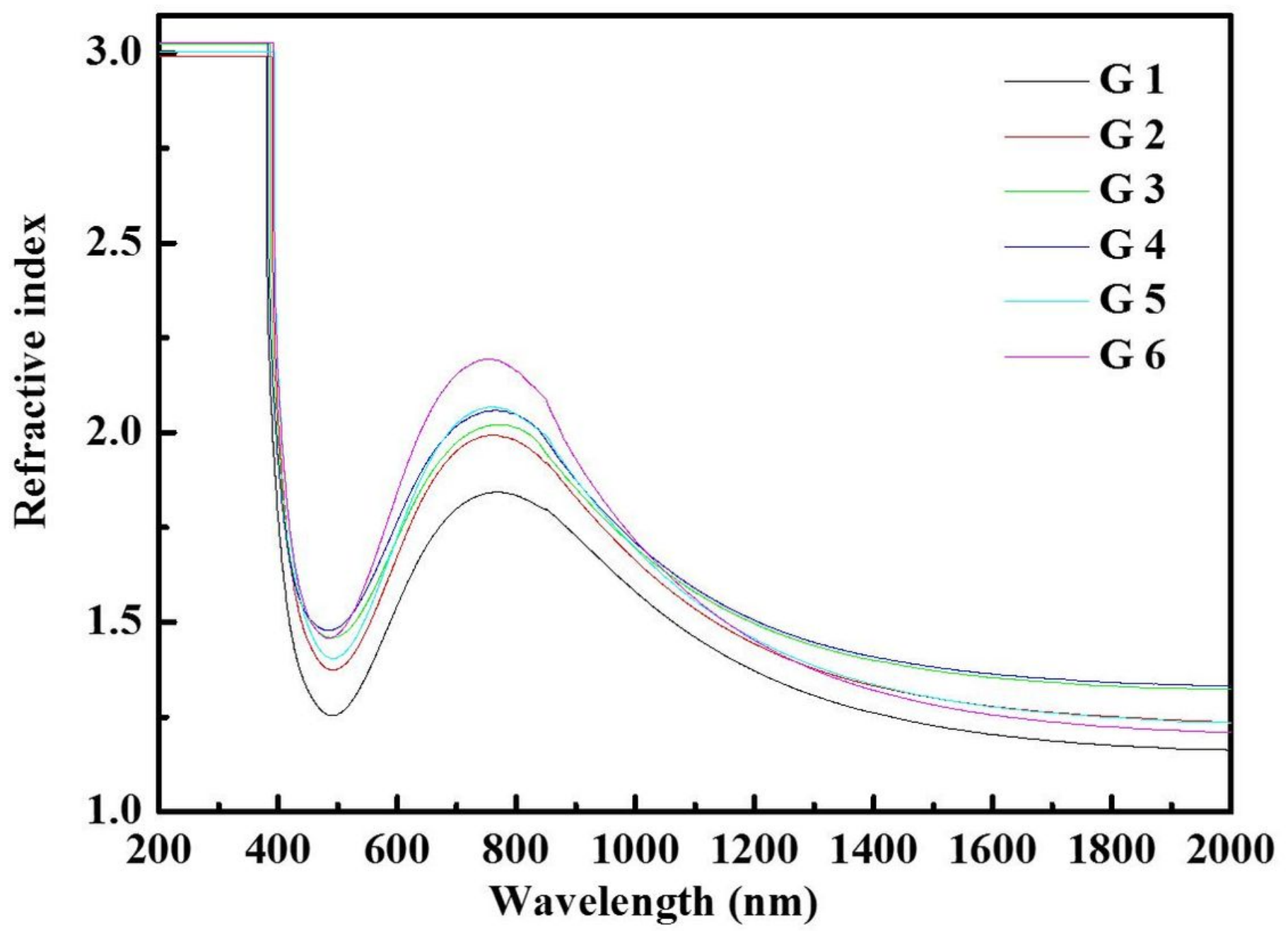

Figure 8

Refractive index of the prepared glasses. 

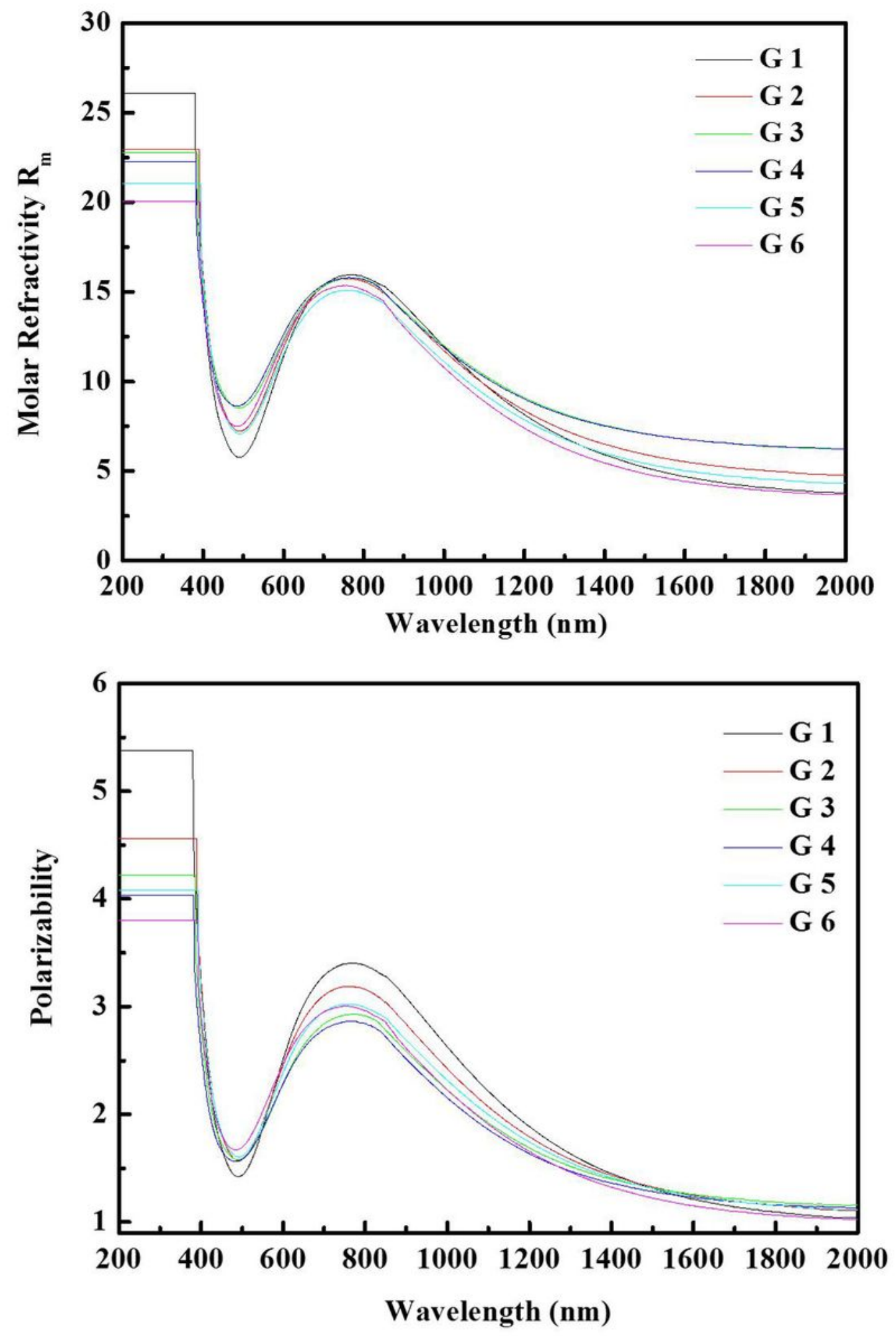

Figure 9

Molar refractivity of the prepared glasses. Electronic polarizability of the prepared glasses. 


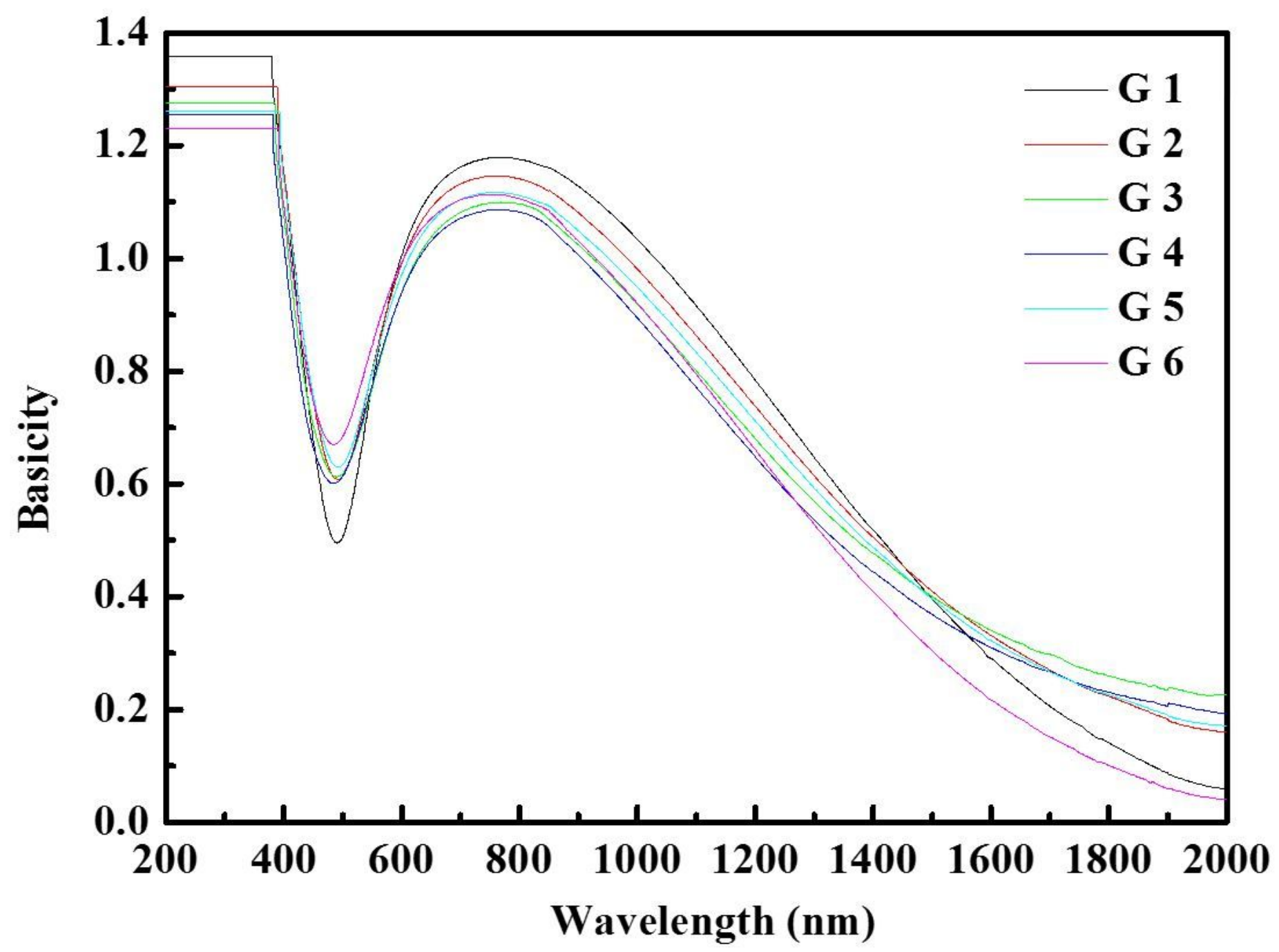

Figure 10

Optical basicity of the prepared glasses. 


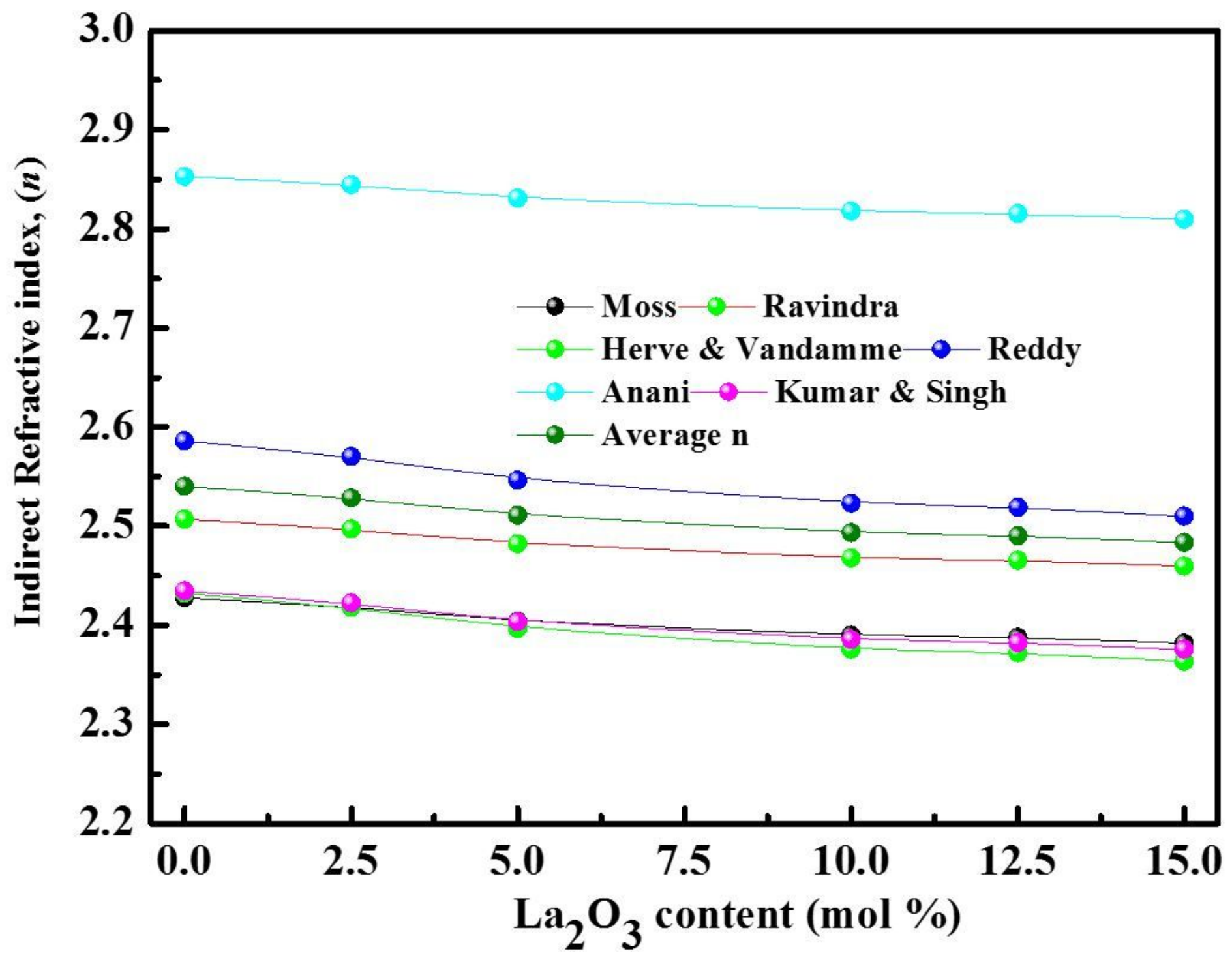

Figure 11

Refractive index of Moss, Ravindra, Herve \& Vandmme, Reddy, Anani, Kumar \& Singh and Average (n) according to indirect bandgap for glass samples 


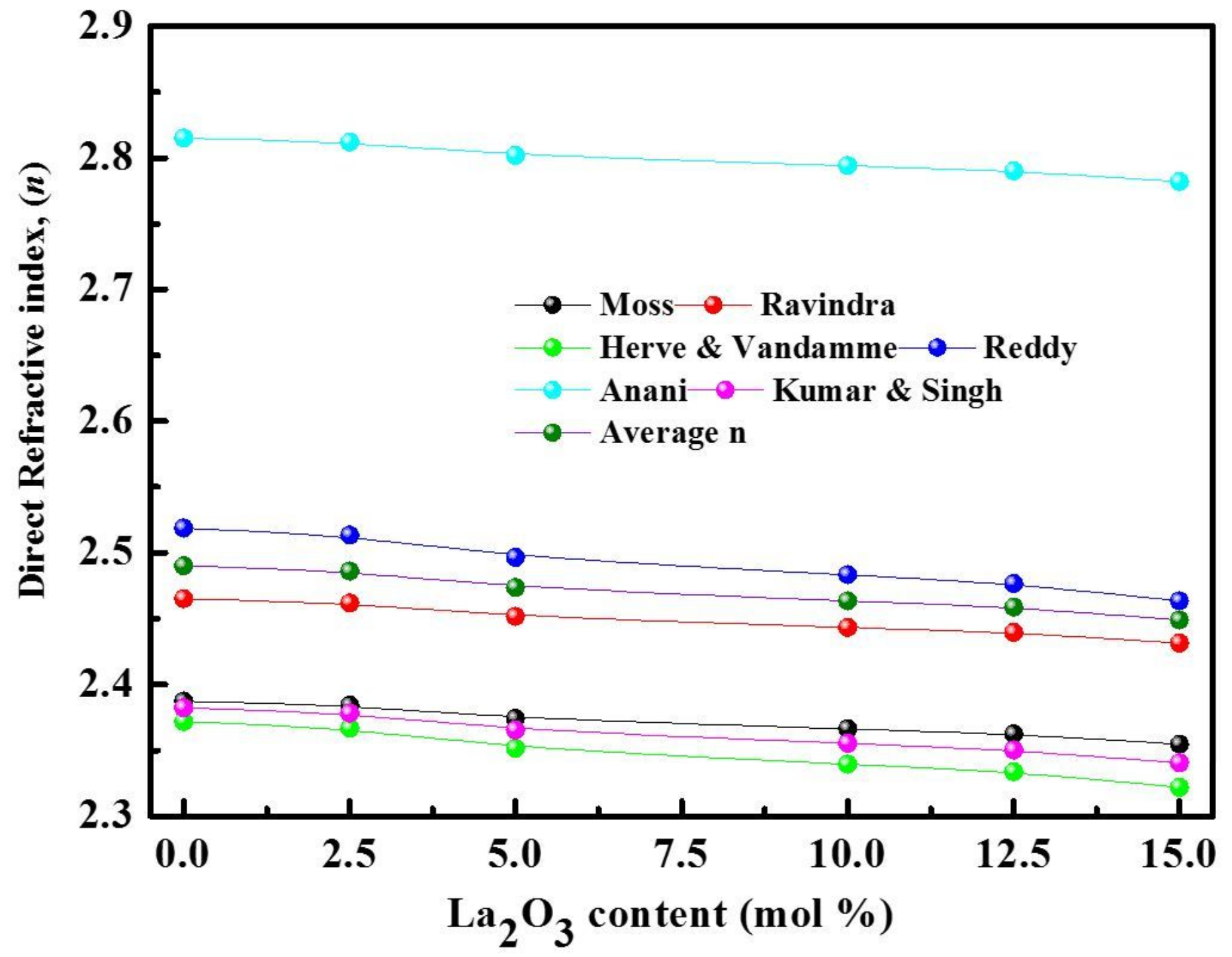

Figure 12

Refractive index of Moss, Ravindra, Herve \& Vandmme, Reddy, Anani, Kumar \& Singh and Average (n) according to direct bandgap for glass samples 

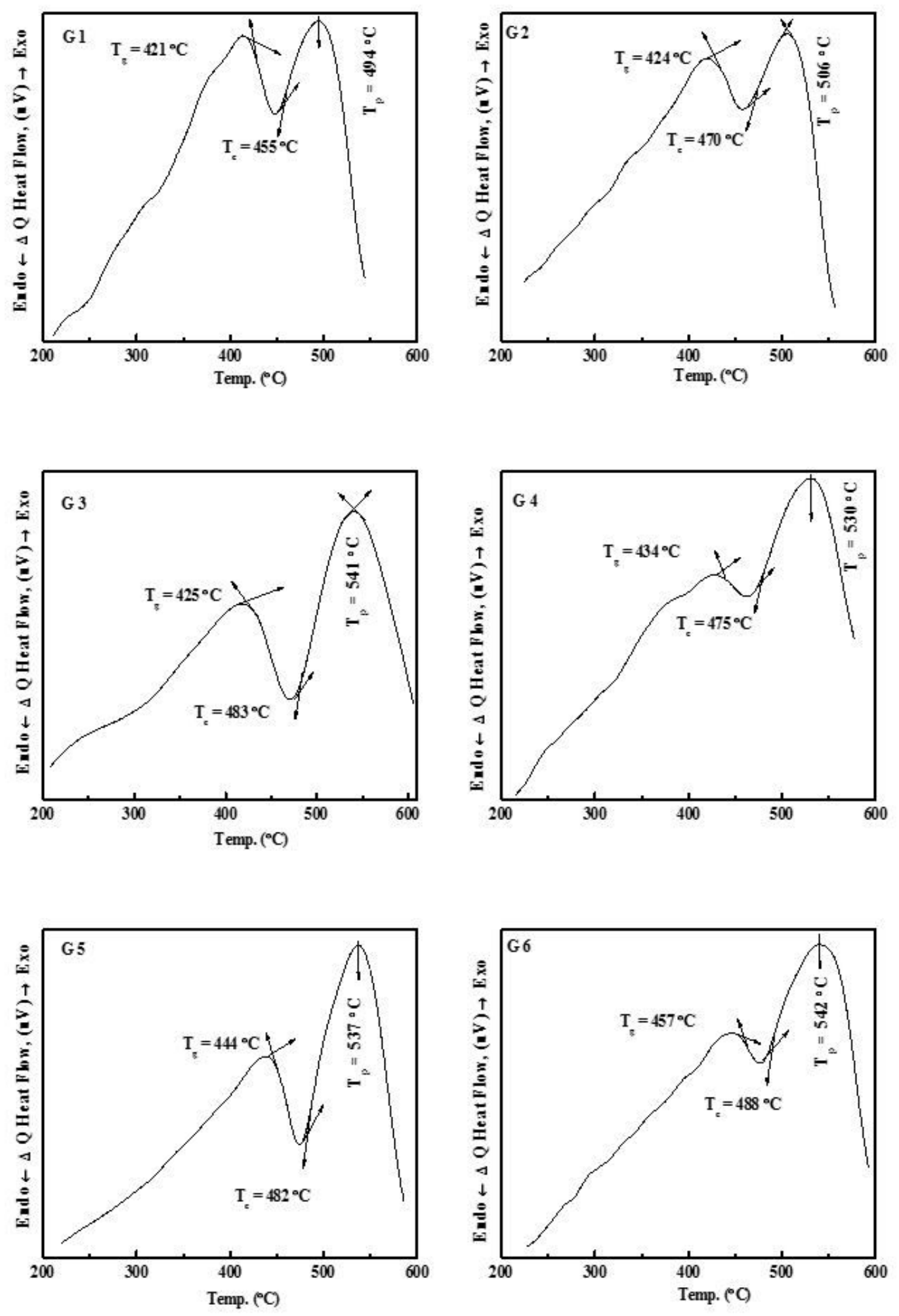

Figure 13

DTA of the investigated glasses. 

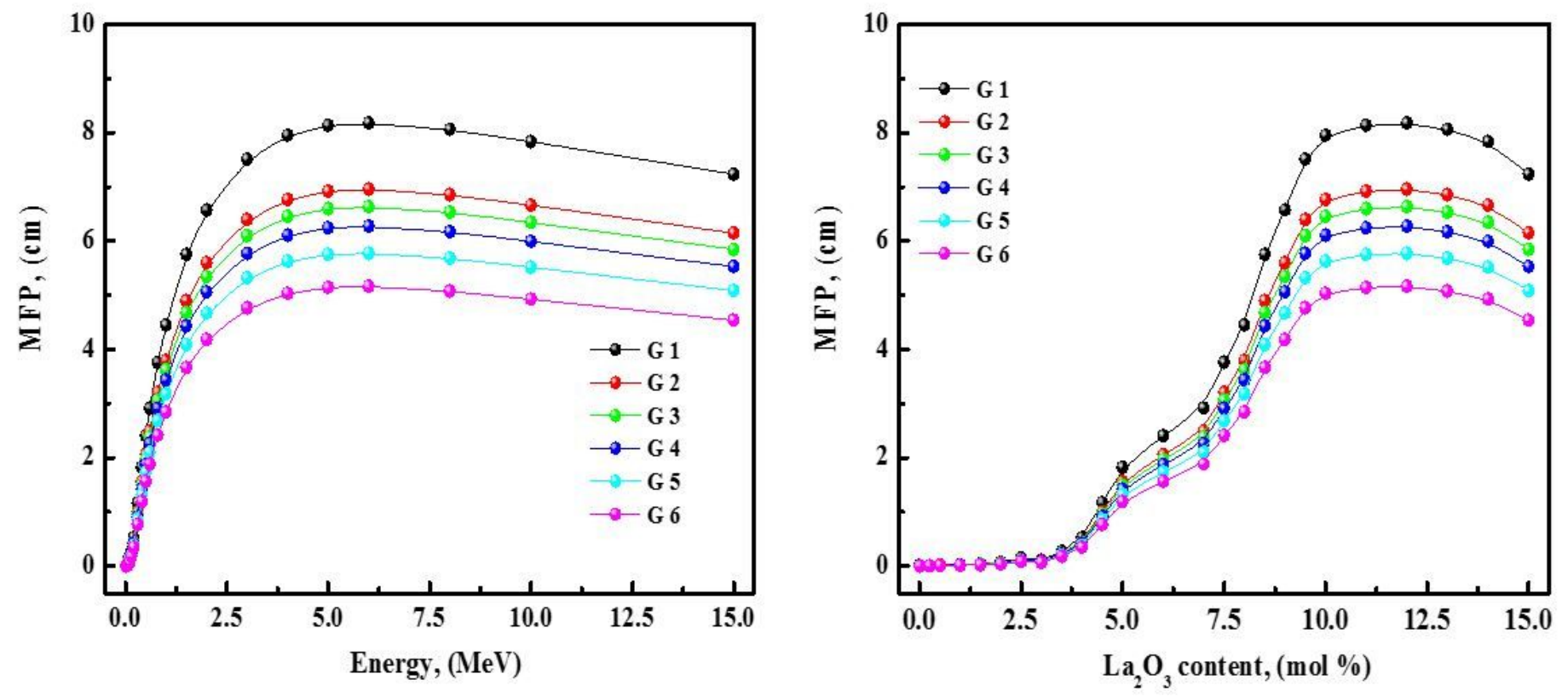

Figure 14

The MFP for the prepared glasses as a function of photon energy and La2O3 content. 


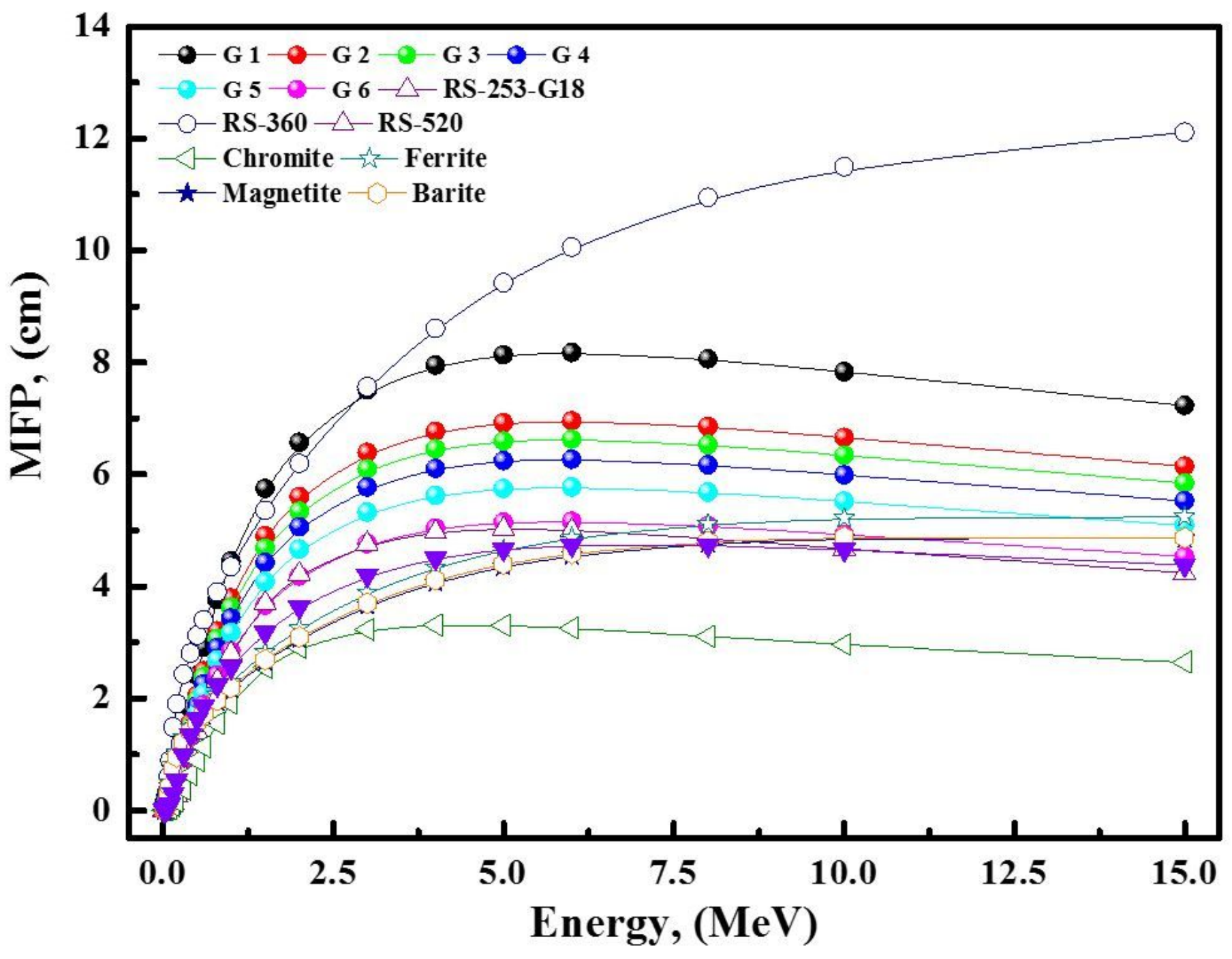

Figure 15

The comparison of MFP for the prepared glasses as a function of photon energy with standard materials. 


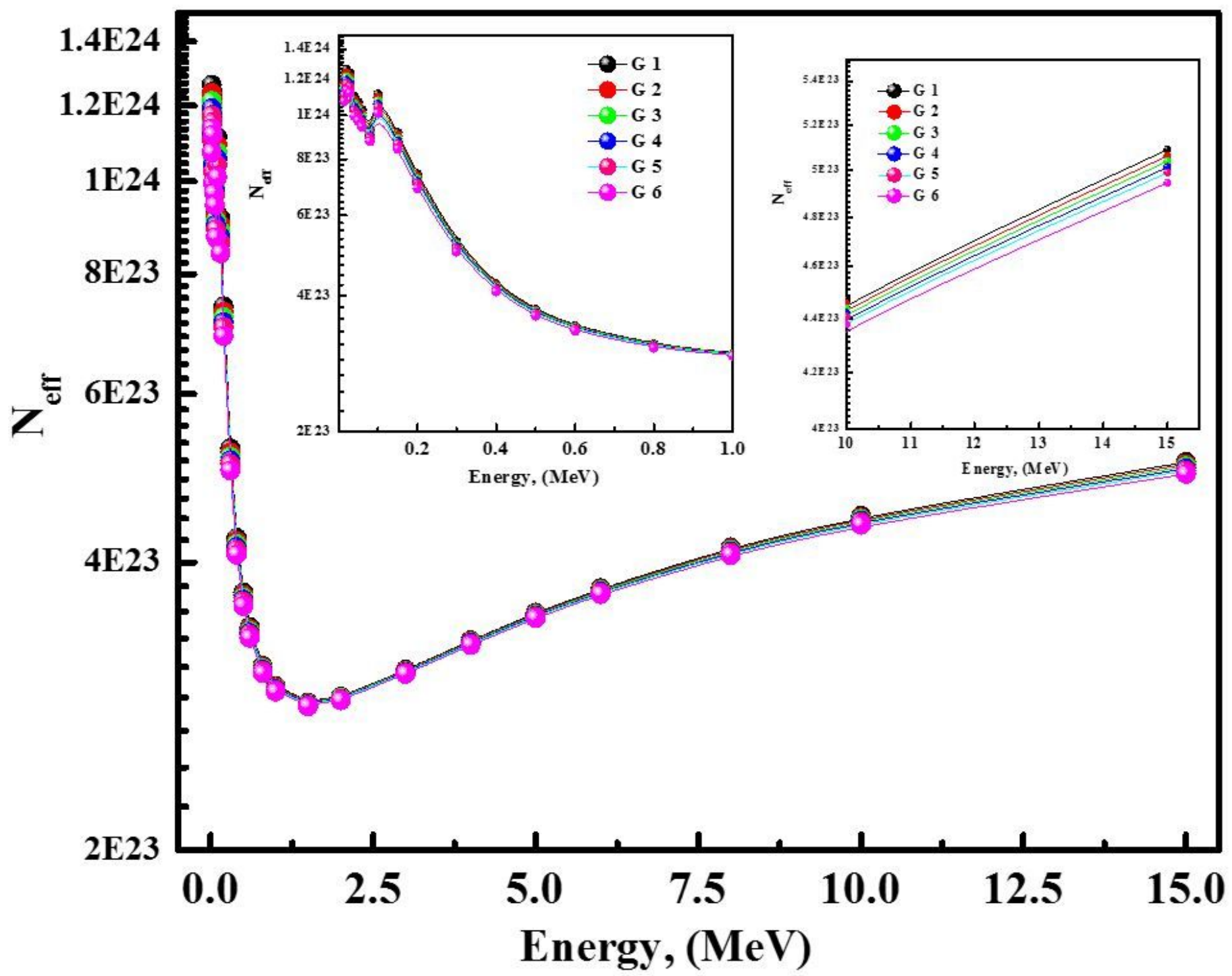

Figure 16

The (Neff) for the prepared glasses as a function of photon energy. 


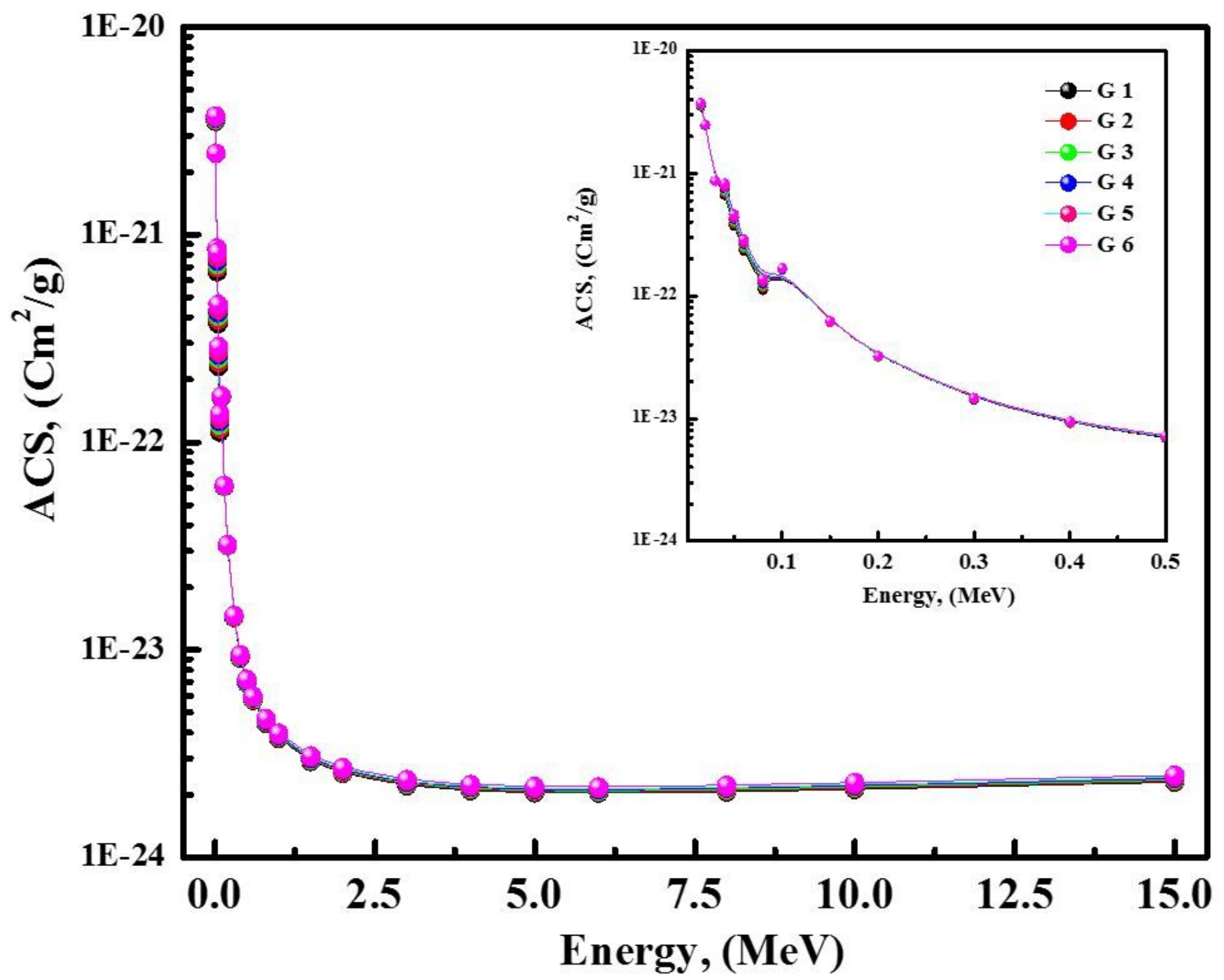

Figure 17

The ASC for the prepared glasses as a function of photon energy. 


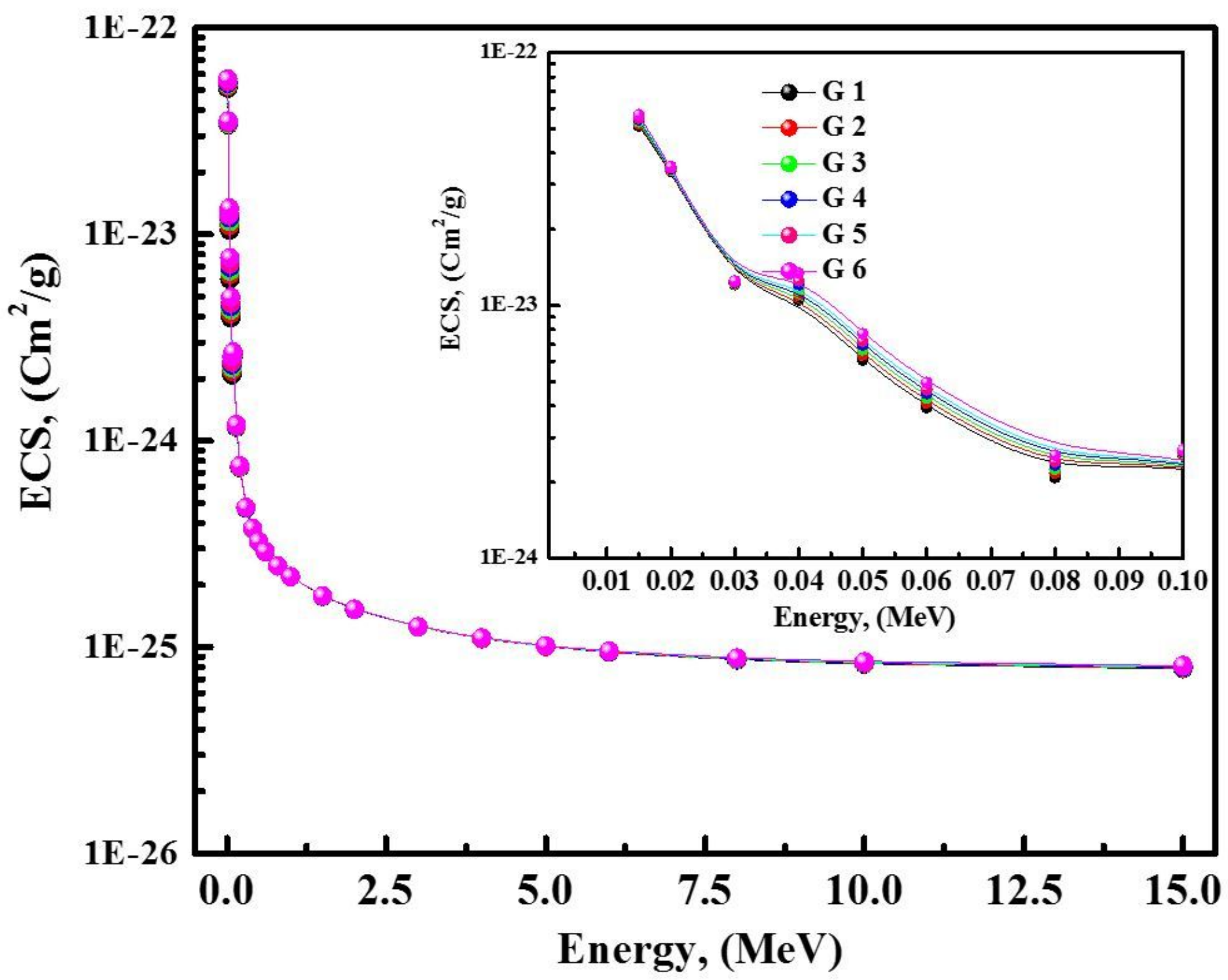

Figure 18

The ECS for the prepared glasses as a function of photon energy. 


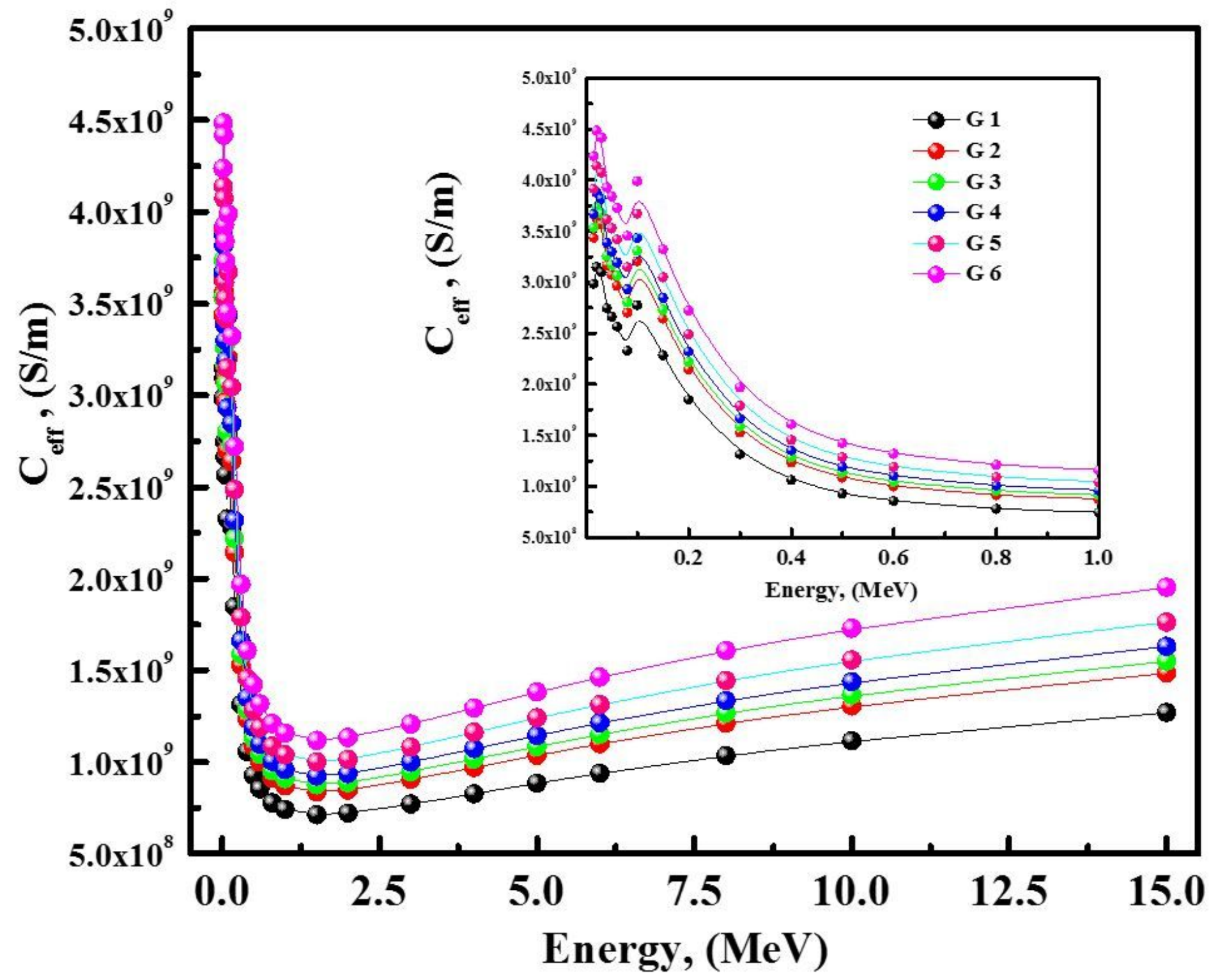

Figure 19

The Ceff for the prepared glasses as a function of photon energy. 


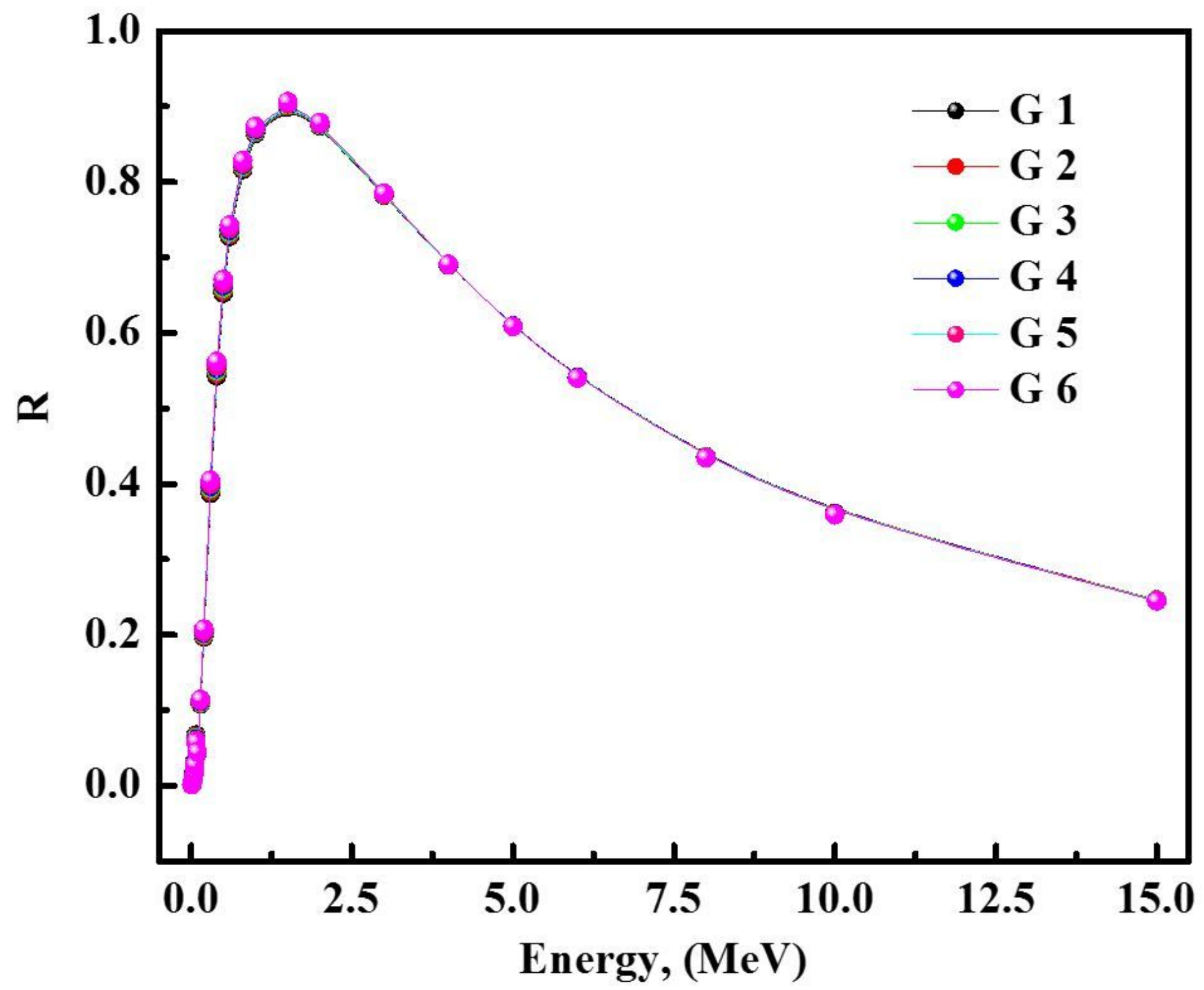

Figure 20

Effective removal cross-through ( $\Sigma R)$ for the prepared glasses as a function of photon energy. 


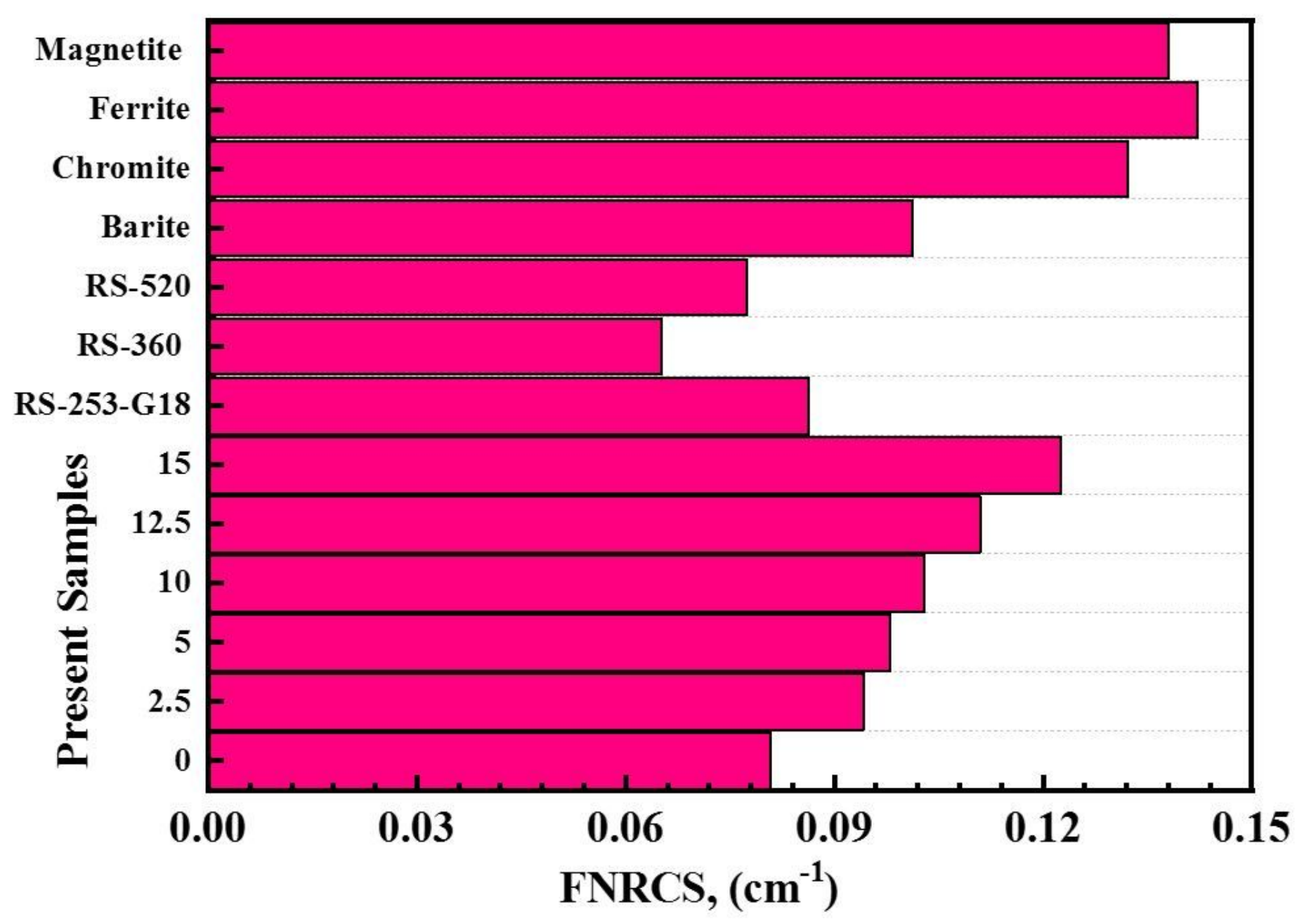

Figure 21

FNRCS for the prepared glasses comparison with standard materials. 